\title{
SOME CONFUSING MATTERS RELATING TO ARBITRATION UNDER THE UNITED STATES ARBITRATION ACT
}

\author{
Wesley A. Sturges* and Irving Olds Murphy $†$
}

This is a review of the judicial administration of the United States Arbitration Act. $^{1}$ It is restricted chiefly to matters relating to the qualification of arbitration

* Dean and Edward J. Phelps Professor of Law, Yale Law School. Chairman, Board of Directors, American Arbitration Association. Author, Commercial Arbitrations and Awards (1930).

† Third year student, Yale Law School, and Student Assistant in Instruction, Yale Law School.

1 The legislation was first enacted in 1925. 43 STAT. 883 (1925), 9 U. S. C. $\$ \$ 1-15$ (1946). It was approved February 12, 1925. Section 15 provided that the Act should take cffcet "on and after the Ist day of January next after its enactment, [namely, January $x$, 1926] but shall not apply to contracts made prior to the taking effect of this Act." This restriction of the application of the Act re arbitration agreements made prior to the foregoing effective date of the Act, was recognized and applied in Ex parte di Simone, 36 F.2d 773 (2d Cir. 1929) on appeal from The Volsinio, 32 F.2d, 357 (E. D. N. Y. 1929) in which the restriction appears to have passed unnoticed.

Section ${ }^{4} 4$ of the Act provided: "That this Act may be referred to as "The United States Arbitration Act." "

Legislative reports upon the Act while it was pending in the Congress as a bill are as follows: House Committee ON Judiciary Report (Committee Report 96), 68th Cong., ist Sess., accompanying H. R. 646, United States Arbitration Act of February 12, r923, referred to in this Article as H. R. No. 96 and Senate Report No. 536, 68th Cong., Ist Sess., referred to in this Article as SEN. Rep. No. 536.

The statute was carried into The Code of the Laws of the United States of America, 44 Stat. 167, Title 9, entitled "Arbitration" (1926). In the Preface to this Code of the Laws of the United States it is stated that: "This Code is the official restatement in convenient form of the generpll and permanent laws of the United States in force December 7, 1925, now scattered in 25 volumesi.e., the Revised Statutes of 1878 , and volumes 20 to 43 , inclusive, of the Statutes at Large. No new law is enacted and no law repenled. It is prima facie the law. It is presumed to be the law. The presumption is rebuttable by production of prior unrepealed Acts of Congress at variance with the Code" (44 Stat. v).

Subsequently the statute was included in the United States Code, 1940 cdition, as Title 9, cntitled "Arbitration."

In 1947 this legislation was repealed, with the proviso, however, that "any rights or linbilitics now existing under such repealed sections or parts thereof shall not be affected by such repeal." The original Act and Title 9 of the U. S. C., I940 Edition, were reenacted except that former Section 14, supra, naming the Act, was omitted and former Section 15 was renumbered as Section 14 and amended to read: "This title shall not apply to contracts made prior to January 1, 1926." 6r Srat. 669 (1947), 9 U. S. C. \$I4 (Supp. 195I).

The original Act was entitled "An Act to make valid and enforceable written provisions or agreements for arbitration of disputes arising out of contracts, maritime transactions, or commerce among the States or Territories or with foreign nations." 43 STAT. $88_{3}$ (1925).

The 1947 Act was entitled "An Act to codify and enact into positive law, title 9 of the United States Code, entitled "Arbitration." "Then followed the enacting clause as follows: "Be it entacted by the Senate and House of Representatives of the United States of America in Congress assembled, That Title 9 of the United States Code, entitled 'Arbitration,' is codified and enacted into positive law and may be cited as '9 U. S. C., $\S$; as follows." This Act incorporated catch lines preceding each section in the body of the Act which were the same as those in THe Code of THE Laws of THE UNited States of America, 44 STAT. 167 , Títle 9, and in 9 U. S. C., 1940 Edition. In the 1947 Act they were not included in the section as in 1940 and the prior Code of the Laws of the United States; thcy were placed above the section. Above "§I" is the catch line: "'Maritime 'Transactions' and 'Commerce' Defined; Exceptions to Operation of Title"; above " $\$ 2$ ": "Validity, Irrevocability, and Enforcement of 
agreements under the Act and to the remedies provided in the Act to render such agreements irrevocable and enforceable. Accordingly, consideration of judicial determinations upon the first five sections of the Act constitutes the major part of this article. The review is intended to point up a variety of issues many of which are important to those who may be concerned with arbitration of either commercial or labor controversies under the Act. Some of these questions derive in part from frailties in drafting the Act and in part from views advanced by some of the courts in resolving those frailties in the course of litigation. Some accrue more directly from the case law made by the courts without much reference to limitations or uncertainties of statutory text. In some instances contradictory determinations of the same issue have been made by two or more courts of appeals. In some instances decisions by the district courts would escape these contradictory determinations on grounds not considered by the court of appeals. Doubtless some day the Supreme Court will resolve some of these diversities. In the meantime, it must be reckoned that the law of the Act may be different in one or more respects in one circuit from what it is in another.

It may be noted, in passing, that these diversities and contradictions are not readily correlated with any declared attitude of the judges toward the Act or toward arbitration or arbitration agreements generally. Common law tradition has taught judges and lawyers alike to look askance upon arbitration agreements prior to award rendered." Some judges who have commented upon the matter have urged a "new

Agrecments to Arbitrate"; above "\$3": "Stay of Proceedings Where Issue Therein, Referable to Arbitration"; above "\$4": "Failure to Arbitrate Under Agreement; Petition to United States Court Having Jurisdiction for Order to Compel Arbitration; Notice and Service Thereof; Hearing and Determination"; above "\$5": "Appointment of Arbitrators or Umpire." Other catch lines appear above the remaining sections.

This Act was approved July 30, 1947. 6I STAT. 669 (1947), 9 U. S. C. $\$ \S I-14$ (Supp. 195I). Except in the foregoing matters the texts of the original and subsequent enactments appear to be substantially the same.

The foregoing detail might have seemed inconsequential, except that the Court of Appeals for the Third Circuit has recently concluded that the foregoing addition of the catch line above $\$ \mathrm{r}$, was sufficient cause to reverse certain of its views taken in earlier cases. See Amalgamated Association of Street Etc. Employees v. Pennsylvania Greyhound Lines, r92 F.2d 3ro (r95I) discussed infra, p. 6r4. General references to the codification also appear in Uniao De Transportadores Para Importacao E Comercio, Ltda. v. Companhia De Navegacao Carregadores Acoreanos, 84 F. Supp. 582 (E. D. N. Y. 1949), and in International Union United Furniture Workers v. Colonial Hardwood Flooring Co., 168 F.2d 33 (4th Cir. I948).

In this article the legislation is generally referred to as the United States Arbitration Act, or the Act, and, except as otherwise indicated, all references to, and quotations from, the Act are to and from the 1947 Act.

${ }^{3}$ Common law revocability and non-enforceability have been ruled into such agreements in almost all American jurisdictions where the issues have been adjudicated (in several jurisdictions the issues have never been determined). Common law revocability rests on two particulars: ( $x$ ) revocability of the agreement and of the authority of all persons under it by due notice given by a-party thereto before award rendered thereunder; and (2) revocability by action, whereby a party can sue in court in disregard of the arbitration agreement and the party-defendant cannot effectively plead the agreement for a stay pending arbitration, nor in abatement or in bar of the action. These two specifications of common law revocability are frequently referred to in this article as "revocability by notice" and "revocability by action," respectively.

Common law non-enforceability refers to the denial of any remedy seeking specific performance of 
orientation," and that the Act should not be given "a grudging type of construction carried down from the days of judicial hostility to all arbitration agreements." Others have voiced traditional warnings against arbitration. The impact of the particular view is sometimes rather clearly recognized in the decision; in other cases it is not.

In I942, Judge Frank, in an opinion for the Court of Appeals for the Second Circuit, ${ }^{3}$ after an extended review of Anglo-American rationale for common law revocability and non-enforceability of arbitration agreements, assigned the substance of its being to "judicial hostility to arbitration," and urged a "new orientation" in causes coming under the Act. He said: ${ }^{5}$

In the light of the clear intention of Congress, it is our obligation to shake off the old

the arbitration agreement such as a general decree against the recalcitrant party to perform, or court appointment of part or the whole of an arbitral board with power to act when the recalcitrant party refuses to cooperate in that particular.

This common law non-enforccability rests more in judicial lore than in positive decisions. The decisions ruling common law revocability have been thought, however, to indicate a high degrec of probability of correlative decisions of non-enforceability were the relief to be sought.

Common law revocability and non-enforceability have been read into both classes of arbitration agreements in general usage, namely, ( 1 ) provisions for arbitration of controversics which may arise between the parties in the future, and (2) agreements of submission of existing controversics.

In a few states common law revocability (by action, at least) of arbitration provisions in contracts is more or less precisely codified by local statute. Idaho, Missouri, Montana, North Dakota, Oklahoma, and South Dakota have such statutory provisions. A similar piece of legislation in Pennsylvania was held an unconstitutional impairment of freedom of contract. Adinolf v. Hazlett, $242 \mathrm{~Pa} .25,88$ Atl. 869 (1913). See Sturges, Commercial Arbitrations and Awards, §is (1930).

The tradition of common law revocability and non-enforccability of arbitration agreements stands in sharp contrast from the common law conclusiveness and finality which are accorded awards and from the tradition of the courts both in equity and at law (and of the arbitration statutes) to narrow the instances or causes for which an award, once rendered, will be vacated or denied enforccment. See STuRges, op. cit. supra, \$235.

${ }^{3}$ Kulukundis Shipping Co. v. Amtorg Trading Corp., 126 F.2d 978 (2d Cir. 1942).

IId. at 985 . Some courts have thought it more appropriate to refer common law revocability (by action, at least) to the quite common constitutional provision that: ". . . all courts are open, and every person, for an injury done him in his land, goods, person, or reputation, shall have remedy by due course of law:" Baltimore \& Ohio R. Co. v. Stankard, 56 Ohio St. 224, 231-232, 46 N. E. 577,579 (1897). See also, Cocalis v. Nazlides, 308 Ill. I52, I39 N. E. 95 (1923).

And if common law revocability (by action) of provisions to arbitrate future disputes were disregarded some of the worst consequences that might result have been judicially presented as follows: "But a party cannot bind himself by contract in advance to renounce his right to appeal to the courts for the redress of wrongs. If this could be done an association might be formed in the state which would renounce our constitution and laws, and set up a different system of government for themselves, and in case of wrongs and oppression they would be debarred from resorting to our courts, and would be compelled to submit to the decisions of their own tribunals, and would most likely become dissatisfied and disorderly, resulting in riot and bloodshed." Mycrs v. Jenkins, Admr., 63 Ohio St. 101, 120, 57 N. E. ro89, 1093 (I900) (italics supplied).

1 26 F.2d at 985 . Absent applicable arbitration statutes, rare have been the instances of judicial "shake off" of traditional common law revocability or non-enforceability of arbitration agreements. It did happen, however, with respect to an arbitration provision in a written collective bargaining agreement in Bell v. Western Ry. of Alabama, 228 Ala. 328, 153 So. 434 (1934). The precise issue was revocability by action; it was denied. Consult also, with respect to an arbitration provision in a written construction contract, Park Construction Co. v. Independent School District, 209 Minn. 182, 296 N. W. 475 (1941) with its citation in Knutson v. Lasher, 219 Minn. 594,18 N. W. $2 \mathrm{~d} 688$ (1945).

That common law revocability by action of arbitration provisions in written contracts was rulcd out by the supreme courts of Colorado and Washington in their first decisions upon the issue, and that such revocability was denied in Pennsylvania with respect to such arbitration provisions which "named" the arbitrator, see STurges, op. cit. stipta note $2, \$ 15$. 
judicial hostility to arbitration. Accordingly, in a case like this, involving the federal Act, we should not follow English or other decisions which have narrowly construed the terms of arbitration agreements or arbitration statutes.

Later on in his opinion, however, Judge Frank saw fit on behalf of the court to caution, if not to chide, the "more enthusiastic" sponsors of arbitration against regarding it "as a universal panacea." "We doubt," he emphasized, "whether it will cure corns or bring general beatitude. Few panaceas work as well as advertised."

In $193^{8}$, Judge A. $N$. Hand, in the same court, in a proceeding in admiralty and involving the Act, had served a judicial warning of rather traditional tenor to parties relating to arbitration as follows: ${ }^{7}$

Arbitration sometimes involves perils that even surpass the "perils of the seas." Cf. Marchant v. Mead-Morrison Mfg. Co., 252 N. Y. 284 , I69 N. E. $3^{86 .}$ Whether in any particular instance it is a desirable risk is not for us to say. It is a mode of procedure fostered by statute and in the present case invoked under the agreement of the parties. If they consent to submit their rights to a tribunal with extensive powers and subject to a most restricted review, they cannot expect the courts to relieve them from the effect of their deliberate choice.

In the third circuit in 1943 , in determining that Section 3 should be construed broadly and not restricted to arbitration provisions in "maritime transactions" or contracts involving "commerce" as covered in Sections I and 2 of the Act, Judge Goodrich declared the approach of this Court of Appeals to the Act as follows: "The generality of the language used in the statute [Section 3] does not suggest any self-imposed limitation. Nor do we think that the 'congressional approval of arbitration'8 should be so limited by implication, by a grudging type of construction carried down from the days of judicial hostility to all arbitration agreements." Again, ". . . we think the Act is entitled to a construction which will accomplish its purpose, and should not be hedged about with imagined limitations, as has been done in some instances"; and "we should not choke the arbitration process which has been given congressional approval by the fetters of earlier judicial conceptions."

\section{I}

General Pattern of Act

The Act purports to embrace (I) a written provision "in any maritime trans-

- 126 F.2d at 987 n. 32.

${ }^{7}$ In re Canadian Gulf Lines Limited, $98 \mathrm{~F} .2 \mathrm{~d}$ 7Ir, $7 \mathrm{I}_{4}$ (2d Cir. 1938). See also: Judge Garrecht in American Guaranty Co. v. Caldwell, 72 F.2d 209 (gth Cir. 1934); Judge Hutcheson in American Sugar Refining Company v. The Anaconda, 138 F.2d 765 (5th Cir. 1943).

${ }^{8}$ This quotation is from Justice Brandeis' opinion in Shanferoke Coal \& Supply Corp. v. Westchester Service Corp., 293 U. S. 449, 453 (1935).

'Donahue v. Susquehanna Collieries Co., ${ }^{3} 8$ F.2d 3, 5, 6, 7 (3d Cir. x943).

See also: District Judge McGranery, in United Office \& Professional Workers of America, C.I.O. v. Monumental Life Ins. Co., 88 F. Supp. 602 (E. D. Pa. I950); District Judge Weinfeld, in Lewittes \& Sons v. United Furniture Workers, 95 F. Supp. 85I (S. D. N. Y. 195I); Circuit Judge Evans, in Delaware \& Hudson R. Corp. v. Williams I29 F.2d II (7th Cir. 1942); District Judge Mandelbaum, in The Aakre, 21 F. Supp. 540 (S. D. N. Y. 1937). 
action" or in a "contract evidencing a transaction involving commerce" (subject to the exclusion of certain contracts of employment to be considered below) "to settle by arbitration a controversy thereafter arising out of such contract or transaction or the refusal to perform the whole or any part thereof," and (2) an agreement in writing to submit to arbitration an existing controversy "arising out of such a contract, transaction, or refusal." This is provided by Section 2. Section 2 of the Act with its "catch line reads as follows:

\section{VALIDITY, IRREVOCABILITY, AND ENFORCEMENT OF AGREEMENTS TO ARBITRATE}

\$2. A written provision in any maritime transaction or a contract evidencing a transaction involving commerce to settle by arbitration a controversy thereafter arising out of such contract or transaction, or the refusal to perform the whole or any part thereof, or an agreement in writing to submit to arbitration an existing controversy arising out of such a contract, transaction, or refusal, shall be valid, irrevocable, and enforceable, save upon such grounds as exist at law or in equity for the revocation of any contract.

Subsequent sections of the Act provide precise remedies to effectuate the foregoing declaration of Section 2 that arbitration agreements qualifying thereunder "shall be valid, irrevocable and enforceable." These remedies include motion proceedings to stay the trial of any action, suit or proceeding brought in any court of the United States upon a cause embraced in such arbitration agreement (\$3), to order a recalcitrant party to proceed in compliance with the arbitration agreement $(\$ 4)$, and to procure court appointment of arbitrators to act under the agreement when a party fails or refuses to participate in the original appointment or in filling a vacancy of the arbitral board $(\$ 5)$. Subsequent sections provide for the confirmation, vacation, and modification or correction of awards by motion proceedings ( $\$ \$ 9$, IO, II). Accordingly, the Act follows the general pattern of the general arbitration statutes of California, Connecticut, Hawaii, Louisiana, Massachusetts, New Hampshire, New Jersey, New York, Ohio, Oregon, Pennsylvania, Rhode Island, Washington, and Wisconsin.

II

Scope of Act-Its Tie-Utp to "Maritime Transactions" and "Commerce"

As indicated above, Section 2 of the Act contains the general declaration of policy and purpose of the Act, namely, that provisions for arbitration of future controversies and agreements of submission of existing controversies which qualify thereunder "shall be valid, irrevocable, and enforceable" except for cause as reserved in the saving clause of the Section, namely, "save upon such grounds as exist at law or in equity for the revocation of any contract." In order to qualify under the Act, agreements for arbitration must be either "a written provision" or an "agreement in writing" (\$2). Oral agreements for arbitration are not recognized by the Act.

Motion proceedings under Section 3 are precisely tailored to nullify common law revocability (by action) of arbitration agreements. They look to an order of 
stay of trial of any suit or proceeding brought in any court of the United States upon a cause embraced in an arbitration agreement qualifying under the Act. ${ }^{10}$

Motion proceedings under Section 4 afford summary procedure to gain a general order against a recalcitrant party to a qualifying arbitration agreement that he proceed with the agreement. This remedy overcomes common law non-enforceability of such agreements. Section 5 covers a special aspect of the enforcement of qualifying agreements by providing, as it does, motion proceedings to obtain court appointment of the original arbitral board when the recalcitrant party fails or refuses to participate in the selection thereof according to the agreement, or in filling a vacancy which may otherwise occur.

It remains to consider how the Act ties up arbitration agreements otherwise qualifying thereunder with "maritime transactions" and "commerce." And why that tie-up?

Section 2 of the Act is, by its terms, limited not only to arbitration agreements which are in writing, but also to ( $\mathrm{x}$ ) a written provision in "any maritime transaction" or in "a contract evidencing a transaction involving commerce" to settle a controversy thereafter arising out of such "maritime transaction" or "contract evidencing a transaction involving commerce" (or arising out of the refusal to perform the whole or any part thereof), or (2) a written agreement of submission of an existing controversy arising out of "such a contract, transaction or refusal."

"Maritime transactions" and "commerce" are defined in Section $x$ of the Act. ${ }^{11}$ The Section, with its catch line, reads as follows:

\section{"MARITIME TRANSACTIONS" AND "COMMERCE" DEFINED; EXCEPTIONS TO OPERATION OF TITLE}

\$r. "Maritime transactions," as herein defined, means charter parties, bills of lading of water carriers, agreements relating to wharfage, supplies furnished vessels or repairs to vessels, collisions, or any other matters in foreign commerce which, if the subject of controversy, would be embraced within admiralty jurisdictions; "commerce," as herein defined, means commerce among the several States or with foreign nations, or in any Territory of the United States or in the District of Columbia, or between any such Territory and another, or between any such Territory and any State or foreign nation, or between the District of Columbia and any State or Territory or foreign nation, but nothing herein

\footnotetext{
${ }^{10}$ No specific remedy is provided to overcome common law revocability by notice. None is provided in the state arbitration statutes of like pattern as the United States Act. Indeed, it is difficult to imagine what positive remedy would be practicable to overcome such revocability. Quite clearly the general declaration of irrevocability as set out in Section 2 with respect to arbitration agreements qualifying thereunder is mandatory and self-executing against the party giving the notice. Otherwise, the provisions of Sections 3,4 , and 5 might be brought to naught by a notice of revocation. For illustration of how a court of the United States might be called upon to accord self-executing effect to the general declaration of Section 2 to defeat revocation by notice, consult State ex rel. Fancher v. Everett, 144 Wash. 592, 258 Pac. 486 (1927).

${ }^{11}$ In the original Act of 1925 the matters in this Section I of the 1947 Act were not given a section number; the 1925 Act began with these matters immediately following the enacting clause; there was no Section I to that Act; and the catch line above Section $x$ of the 1947 Act did not appear in the original Act; there were, however, similar lines on the right margin of the Section. Concerning the significance of this detail, see supra note $\mathrm{I}$.
} 
contained shall apply to contracts of employment of seamen, railroad employees, or any other class of workers engaged in foreign or interstate commerce.

It is clear that Sections 2 and I purport to determine what arbitration agreements qualify under the Act. Section I is necessary to the understanding of Section 2 in this connection. These Sections indicate that the Act is based upon written arbitration agreements concerning controversies which develop out of one or more of the designated transactions within the admiralty and maritime jurisdiction of the Congress or out of contracts evidencing transactions within the regulatory powers of the Congress over interstate and foreign commerce. Unless an arbitration agreement covers a controversy arising out of one of these transactions, apparently the Act is not intended to apply. It has been so held with respect to provisions to arbitrate future controversies. ${ }^{12}$ If the agreement is a provision to settle by arbitration a controversy thereafter arising, it must be found in a "maritime transaction" or in a contract evidencing a transaction involving "commerce" to qualify. If it is an agreement of submission of an existing controversy, it is not required to be so located. The source of the controversy is controlling in both cases.

Accordingly, it is thought that the terms of the Act do not extend to arbitration agreements covering controversies arising out of other and different sources even though such controversies may be subject to the established jurisdiction of the courts of the United States either on the grounds of diversity of citizenship of the parties or as arising under a law of the United States. ${ }^{13}$

\footnotetext{
12 This statement is subject to the exception ruled in certain cases considered in the ncxt topic of this article that Section 3 is not so restricted. Some of these cases, however, imply, at least, that the Act otherwise (Sections 4 and 5, in particular) is so restricted. The cases cited hercwith are either contrary to the foregoing decisions on Section 3 and have not been reversed or overrulcd by the court of appeals of the circuit, or they did not involve Section 3. Tejas Development Co. v. MeGough Bros., I65 F.2d 276 (5th Cir. 1947); In re Cold Metal Process Co., 9 F. Supp. 992 (W. D. Pa. 1935) (\$\$4, 5); Watkins v. Hudson Coal Co., 54 F. Supp. 953 (M. D. Pa. 1944) (\$4). See also, comment of Judgc Learned Hand in Shanferoke Coal \& Supply Corp. v. Westchester Supply Corp., 70 F.2d 297 (2d Cir. 1934), quoted infra, note 39; Conley v. San Carlo Opera Co., I63 F.2d 310 (2d Cir. 1947); In re Wisconsin Cent. Ry. Co., 74 F. Supp. 85 (D. Minn. I947).

It seems clear that it is sufficient if the arbitration provision covers a controversy arising out of either a "maritime transaction" or "commerce"; that if derives from a "maritime transaction," it is not necessary that such transaction also constitute "commerce." The Aakre, 21 F. Supp. 540 (S. D. N. Y. 1937). See also The Gerald Fagan, 49 F.2d 215 (2d Cir. I93I); J. V. Lane \& Co., Inc. v. O'Donnell Transp. Co., 9 F. Supp. 39 (E. D. N. Y. 1934).

The limitation of the Act to arbitration agreements covering controversics from the two designated sources attends not only provisions to arbitrate controversies arising in the future, but also agrcements of submission of existing controversies. Section 2, after identifying future disputes provisions as those covering "a controversy thereafter arising out of such contract or transaction, or the refusal to perform the whole or any part thereof," identifies a written agreement of submission of an existing controversy as covering a controversy "arising out of such contract, transaction, or refusal." That state arbitration statutes of the same general pattern as the United States Act are not so restrictive as to the coverage of submissions of existing controversies, see STURGES, op. cit. stipra note $2, \$ 140$.

${ }^{13}$ If the arbitration provision covers a controversy arising out of a contract evidencing a transaction involving interstate commerce (and not from a "maritime transaction" nor from a contract cvidencing a transaction involving foreign commerce or general admiralty jurisdiction) it secms clear that the juris. diction of the federal court to grant the remedy of Section 4 or 5 will depend upon diversity of citizenship of the parties as well as the source of the controversy. Judge Learned Hand has given illustration of this as follows: "A citizen of New Jersey may enforce arbitration against a citizen of New York upon
} 
It is not clear why the Act was so restricted. The legislative reports do not tell why. ${ }^{14}$ The Congress, finding it expedient and desirable to require the courts of the United States to repudiate common law revocability and non-enforceability of written arbitration agreements covering controversies arising out of "maritime transactions" and "commerce" should, it seems, have found it equally expedient and desirable to accomplish the same objectives with respect to like written arbitration agreements covering other and different controversies over which the courts of the United States take jurisdiction by reason of diversity of citizenship of the parties or otherwise.

There has been some judicial suggestion that the Congress did not have constitutional power to do so. This view has been advanced in certain cases involving the Act wherein consideration was given to whether Section 3 is confined to arbitration provisions in "maritime transactions" and in contracts evidencing "commerce," or may be of more general coverage (we give consideration to this particular question in the next succeeding topic of this article). It seems to have been suggested in this connection that arbitration agreements covering controversies arising from the designated sources were fully within "the federal legislative domain," whereas the conferring of "validity to arbitration agreements generally" might be outside the scope of "federal power." At the same time it was further suggested, however, that the stay of trial of suits or proceedings as provided in Section 3 could be extended to all suits or proceedings in the courts of the United States, for Congress is not limited in regulating procedures in the federal courts by any limitations upon its powers to regulate "maritime transactions" or "commerce." It should be emphasized, however, that the question of constitutional power to extend the provisions of all sections of the Act to arbitration agreements covering controversies in addition to those arising out of "maritime transactions" or "commerce" and over which the courts of the United States take jurisdiction only by diversity of citizenship or otherwise was not precisely in issue in these cases. But the point was put by Judge Goodrich in the third circuit as follows: $:^{15}$

The first section defines maritime transactions and commerce. Then the second section proceeds to lay down a rule of substantive law regarding the validity of an agreement for arbitration in case of any maritime transaction or a contract evidencing a transaction involving commerce. Congress was here making a rule concerning subject matter within its own constitutional legislative authority. It was not seeking to confer validity to arbitration agreements generally, a matter outside the scope of federal powers. Instead, it picked out two important classes of transactions within the federal legislative domain and declared the effect of arbitration clauses in agreements concerned therewith.

a contract of sale which requires him to ship the goods from Newark to Manhattan, but not upon one where they are to go from Manhattan to the Bronx. Conversely, a citizen of New York may not come to the District Court to enforce arbitration against another citizen of that state, though the goods must be shipped across a State line." Krauss Bros. Lumber Co. v. Louis Bossert \& Sons, Inc., 62 F.2d 1004, 1006 (2d Cir. 1933).

14 See infra note 16.

${ }^{26}$ Donahue v. Susquehanna Collieries Co., 138 F.2d 3, 5 (3d Cir. 1943) (italics supplied). 
Then in $\$ 3$ the statute deals with the conduct of suits in federal courts; again a subject matter of congressional power. The language becomes general: "any suit or proceeding," upon "any issue referable to arbitration under an agreement in writing for such arbitration" are the words. Congress is not limited, in legislating as to law suits in federal courts, to those suits involving matters where the substantive rights of the parties may be controlled by federal legislation.

Judge Parker, in the fourth circuit, ruling in accord with Judge Goodrich on the precise issue before them, advanced similar views on the question at hand and had reference, in so doing, to the legislative history of the Act. He said $:^{10}$

As introduced into Congress section 2 of the act provided for the validity and enforceability of arbitration agreements "in any contract or maritime transaction or transaction involv-

${ }^{10}$ Agostini Bros. Building Corp. v. United States, 142 F.2d 854,856 (4th Cir. I944) (italics supplied).

We have taken liberties with Judge Parker's last quoted sentence by inserting [arbitration] as indicated. It is believed that he meant "arbitration" contracts generally, because it is clear that the Act concerns the "validity" of such contracts only. With this amendment his text is conformed to that we have quoted from Judge Goodrich.

It may be helpful to supplement Judge Parker's statement of the legislative history of the Act with the following detail.

The original bill (HR ${ }_{4}{ }_{4} 6$ ), as recommended by the Committee on the Judiciary of the House of Representatives, read (disregarding italics and matter in [ ]) as follows in its first two sections:

"Be it enacted, etc., That 'maritime transaction,' as herein defined, means charter parties, bills of lading of water carriers, agreements relating to wharfage, supplies furnished vessels or repairs to vessels, collisions, or any other matters in foreign or interstate commerce which, if the subject of controversy, would be embraced within admiralty jurisdiction; 'commerce' as herein defined, means commerce among the several States or with foreign nations, or in any Territory of the United States or in the District of Columbia, or between any such Territory and another, or between any such Territory and any State or foreign nation, or between the District of Columbia and any State or Territory or foreign nation, but nothing herein contained shall apply to contracts of employment of seamen, railroad employees, or any other class of workers engaged in foreign or interstate commerce.

"Sec. 2. That a written provision in any contract or maritime transaction or ['a contract evidencing a'] transaction involving commerce to settle by arbitration a controversy thereafter arising between the parties out of such contract or transaction, or the refusal to perform the whole or any part thercof, or an agreement in writing to submit to arbitration an existing controversy arising out of such a contract, transaction, or refusal, shall be valid, irrevocable, and enforceable, save upon such grounds as exist at law or in equity for the revocation of any contract."

The House Committee, in reporting the bill favorably, commented upon it in part as follows:

"The purpose of this bill is to make valid and enforceable agreements for arbitration containcd in contracts involving interstate commerce or within the jurisdiction of admiralty, or which may be the subject of litigation in the Federal courts. It was drafted by a committee of the American Bar Association and is sponsored by that association and by a large number of trade bodies whose represcntatives appeared before the committee on the hearing. There was no opposition to the bill before the committec [Italics supplied].

"The matter is properly the subject of Federal action. Whether an agreement for arbitration shall be enforced or not is a question of procedure to be determined by the law court in which the procceding is brought and not one of substantive law to be determined by the law of the forum in which the contract is made. Before such contracts could be enforced in the Federal courts, therefore, this law is essential. The bill declares that such agreements shall be recognized and enforced by the courts of the United States. The remedy is founded also upon the Federal control over interstate commerce and over admiralty. The control over interstate commerce reaches not only the actual physical interstatc shipment of goods but also contracts relating to interstate commerce. ..." H. R. No. 96.

Before the bill was reported favorably by the Senate Committee on the Judiciary the words in Sections $I$ and 2 as italicized above were deleted and the words in [ ] were added. SEN. REP. No. 536.

There is no explanation in the Report why these changes were made.

More of the Report is set forth, infra, p. 603. 
ing commerce." The Senate Committee struck the word "contract" from the section and rewrote the language in its present form, so as to cover only maritime transactions and transactions involving interstate and foreign commerce. Senate Report No. 536, 68th Congress, Zip Mfg. Co. v. Pep Mfg. Co., D. C. 44 F.2d r84. This was evidently done because it was realized that Congress had no power to legislate with respect to the validity of [arbitration?] contracts generally but only as to the validity of those which related to matters subject to its control.

Judge Parker appears, however, to have amended his foregoing views in the subsequent case of International Union United Furniture Workers v. Colonial Hardwood Flooring Co. ${ }^{17}$ In this later case he recognized that the remedies provided in Sections 4 and 5 of the Act are fully within the plenary jurisdiction of the Congress to regulate procedure in the federal courts as is the remedy provided in Section 3. Reviewing the legislative history of the Act he noted once more the elimination of "any contract" from Section 2 but further observed that Sections 3, 4, and succeeding sections providing, as he called it, for "compulsory arbitration under court direction," remained unchanged. Since these provisions deal with "procedure in the courts" it was his view that the Congress had "plenary jurisdiction." It seems clear that Section 2, in declaring that qualifying arbitration agreements "shall be valid, irrevocable and enforceable" constitutes a mandate to the courts of the United States to make such agreements so, and to accord the parties the remedies of Sections 3,4 , and 5 to accomplish those ends. It does not purport to deal with the "validity of contracts [or arbitration contracts] generally"; it is a directive only to the courts of the United States and designates what remedies (Sections 3, 4, and 5) those courts shall accord the qualifying agreements.

In line with Judge Parker's last cited views, it is doubted that any constitutional limitation required the Congress to restrict the Act with its mandate to the federal courts to written arbitration agreements covering controversies having their source in "maritime transactions" or "commerce" as it appears to have done. It is believed that the Act could have been extended as well to arbitration agreements covering other and different controversies which otherwise may be litigated in the courts of the United States under their established jurisdiction such as in cases of diversity of citizenship of the parties or otherwise.

This conclusion is based upon the identification by the courts of the United States of issues of revocability and enforceability of arbitration agreements as matters of remedy or procedure which as respects the federal courts, are within the plenary power of the Congress. We also note the want of substance of traditional common law revocability and non-enforceability of arbitration agreements and the nature of the legislative reform in arbitration statutes like the United States Act.

We present these considerations first, without reference to the decision of the Supreme Court in Erie R. Co. v. Tompkins, ${ }^{18}$ and then taking into account the ruling in that case and such subsequent cases as seem pertinent.

${ }^{27}$ I 68 F.2d 33 (4th Cir. 1948).

$$
{ }^{18}{ }_{304} \text { U. S. } 64 \text { (1938). }
$$


In a variety of cases decided before Erie $R$. Co. v. Tompkins and before the United States Act became effective the issue of revocability of arbitration provisions was held by the courts of the United States to be a matter of "remedy" or "procedure" (not "of right") to be determined by them exclusively according to the law of the forum. ${ }^{19}$ The issue was identified and determined as a question of "general law; i.e., one wherein the courts of the United States are not bound to follow or conform to the decisions of the state jurisdiction in which they may happen to sit."20

On the same basis the federal courts, prior to the United States Act, refused to honor a state or foreign arbitration statute, that, otherwise, might be applicable to render the arbitration agreement irrevocable. Revocability again was ruled by the federal courts in accord with traditional common law. One of the first of these decisions, Atlantic Fruit Co.v. Red Cross Line, ${ }^{21}$ involved a libel in admiralty upon a charter party. The charterers sued the owners of the vessel to recover alleged overpayments of charter hire. In refusing to stay the proceedings in accord with the New York Arbitration Law, Circuit Judge Mack observed as follows: "Arbitration statutes or judicial recognition of the enforceability of such provisions do not confer a substantive right, but a remedy for the enforcement of the right which is created by the agreement of the parties."22 And "it is not within the power of the 19 These rulings were made in cases involving revocability by action. They related to provisions
in written contracts to arbitrate controversies that might arise between the parties in the future. By
pertinent foreign, or state, law deemed applicable to the provision it was irrevocable by action. The
provisions were held revocable by action by the federal court.

In the following cases so ruling the jurisdiction of the federal court was invoked by libcl in ad. miralty: United States Asphalt Refining Co. v. Trinidad Lake Petroleum Co., 222 Fed. roo6 (S. D. N. Y. 1915); The Eros, 24I Fed. 186 (E. D. N. Y. 1916), aff'd, 251 Fed. 45 (2d Cir. I918); Tatsuuma Kisen Kabushiki Kaisha v. Prescott, 4 F.2d 67o (9th Cir. 1925). See also, Akticsclskabct Korn-ogFoderstof Kompagniet v. Rederiaktiebolaget Atlanten 250 Fed. 935 (2d Cir. I9r8).

Accord, in non-admiralty cases: Mitchell v. Daugherty, 90 Fed. 639 (3d Cir. 1898); Jefferson Firc Ins. Co. v. Bicrce \& Sage, 183 Fed. 588 (C C. E. D. Mich. 1910); Haskell v. M'Clintic-Marshall Co., 289 Fed. 405 (9th Cir. 1923).

${ }^{20}$ The quotation is from United States Asphalt Refining Co. v. Trinidad Lake Petrolcum Co., stipra note 19 , at roIr.

21276 Fed. 319 (S. D. N. Y. I92I). See also, The Eros, 241 Fed. 186 (E. D. N. Y. 1916), aff'd, 251 Fed. 45 (2d Cir. 19r8). Accord, in non-admiralty cases, the United States Act not bcing applicable: Voutrey v. General Baking Co., 39 F. Súpp. 974 (E. D. Pa. 194r); Karno-Smith Co. v. School Dist. of Scranton, 44 F. Supp. 860 (M.D. Pa. 1942); California Prune \& Apricot Growers' Ass'n v. Catz American Co., 6o F.2d 788 (9th Cir. 1932) reported, infra, p. 623. Compare Pacific Indemnity Co. v. Ins. Co. of No. America, 25 F.2d 930 (9th Cir. 1928) in which stay of trial was granted pursuant to the California arbitration statute. No reference was made to the United States Act, nor was the matter now under consideration discussed.

22276 Fed. at 323 (italics supplied). The decision was affirmed on appeal with an opinion of like tenor, 5 F.2d 218 (2d Cir. I924). In the interim, the Supreme Court had held that the arbitration agreement involved in the case was enforceable by application for a general order to procecd under the New York Arbitration Law in the New York Supreme Court, notwithstanding the controversy arose out of a charter party and was therefore a cause arising within the "admiralty and maritime jurisdiction" of the courts of the United States. Red Cross Line v. Atlantic Fruit Co., 264 U. S. ro9 (I924). Id. at 123, I24. Said Justice Brandeis for the Supreme Court: "By reason of the saving clause [United States Judicial Code, $\$ 256,28$ U. S. C. A. \$37 I] state courts have jurisdiction in personam, concurrent with the admiralty courts, of all causes of action maritime in their nature arising under charter parties. . . A A State may not provide a remedy in rem for any cause of action within the admiralty jurisdiction. . . . But otherwise, the State, having concturent jurisdiction, is free to adopt such remedies, and to attach to them such incidents, as it sees fit. New York, therefore, had the 
state to regulate the procedure and practice of a federal court of admiralty."23

In I93r, the Supreme Court likewise identified the United States Act as a matter of "remedy" in Marine Transit Corp. $v$. Dreyfus" in which it was confronted with a challenge of the constitutionality of the United States Act. The point was advanced in admiralty proceedings that if the enforcement provisions of the Act (order to proceed with arbitration) were applied in admiralty, the Act would be incompatible with the judicial power of the United States as extended to cases of admiralty and maritime jurisdiction by Article III of the Constitution. This objection to the Act was denied by the Supreme Court on the ground that the Act was well conceived within the general power of the Congress "to provide remedies in matters falling within the admiralty jurisdiction of the federal courts, and to regulate their procedure."25 The views of the Court in this case as to the identification of the issue as one of "remedy" and those of the Court as advanced in Red Cross Line v. Atlantic Fruit Company ${ }^{26}$ were reiterated by Chief Justice Hughes as follows: ${ }^{27}$

It was because the question was one of remedy only, that this Court decided that a State, by virtue of the clause saving to suitors "the right of a common law remedy," [Judicial Code, $\$ 24(3)$; U. S. C., Title $28, \$ 4 I(3)]$ had the power "to confer upon its courts the authority to compel parties within its jurisdictions to specifically perform an agreement for arbitration, which is valid by the general maritime law, as well as by the law of the State" and is contained in a maritime contract made within the State and there to be performed. Red Cross Line v. Atlantic Fruit Co., supra, at 124. The general power of the Congress to provide remedies in matters falling within the admiralty jurisdiction of the federal courts, and to regulate their procedure, is indisputable. The petitioner contends that the Congress could not confer upon the courts of admiralty the authority to grant specific performance. But it is well settled that the Congress, in providing appropriate means to enforce obligations cognizable in admiralty, may draw upon other

power to confer upon its courts the authority to compel parties within its jurisdiction to specifically perform an agreement for arbitration, which is valid by the general maritime law, as well as by the law of the State, which is contained in a contract made in New York and which, by its terms, is to be performed there.

.. . The Arbitration Law deals merely with the remedy in the state courts in respect of obligations voluntarily and lawfully incturred. It does not attempt either to modify the substantive maritime law or to deal with the remedy in courts of admiralty." Id. at 123, 124 (italics supplied).

${ }^{33} 276$ Fed. at 323 (italics supplied). Only one federal case has been discovered in which this gencral issue was not disposed of by the same identification of the given state arbitration statute. Reference is made to Lappe v. Wilcox, 14 F.2d 861 (N. D. N. Y. 1926). In that case, in an action brought by a Pennsylvania resident against a New York resident in the District Court for the Northern District of New York with diversity of citizenship as the ground of jurisdiction of the court, application for stay of trial based upon the New York Arbitration Law was denied. Notwithstanding the position taken in the earlier decisions in the second circuit (stipra notes 2I, 22) and by the Supreme Court (supra note 22) identifying the New York Arbitration Law as dealing "merely with the remedy in the state courts," the decision was put upon two differently stated grounds as follows: (I) The New York Law could not deprive non-residents of the state, who otherwise could do so, of the right to invoke the jurisdiction of the federal court. (2) The terms of the New York Arbitration Law indicated that it was not intended that it should be enforced by any other courts than those of the state of New York.

${ }^{24} 284$ U. S. 263 (I932).

${ }^{25}$ Id. at 278 (italics supplied).

${ }^{20} 264$ U. S. Iog (1924), supra note 22.

${ }^{27}$ Marine Transit Corp. v. Dreyfus, 284 U. S. $263,277-278,279$ (I932) (italics supplied). 
systems. . . Similarly, there can be no question of the power of Congress to authorize specific performance when that is an appropriate remedy in a matter within the admiralty jurisdiction. ...

In this instance a remedy is provided to fit the engagement. The Congress has authorized the court to direct the parties to proceed to arbitration in accordance with a valid stipulation of a maritime contract, and to enter a decree upon the award found to be regular and within the terms of the agreement. We think that the objection on constitutional grounds is without merit.

It also has been held under the United States Act that stay of trial shall be granted a defendant under Section 3 (the arbitration provision qualifying under the Act) although the action was originally brought in a state court (where the arbitration provision was revocable by local law) but was removed by the defendant to a federal court. The Court of Appeals for the Fifth Circuit in Parry v. Bache .8 $^{\circ}$ so ruled in I942, stating "that the invoked statute being remedial, controls the procedure in the federal court; and that the view the state court might take of the arbitration agreement is wholly immaterial."

Such has been the identification at common law of issues of revocability and enforceability of arbitration agreements by the courts of the United States. They have been held to be matters of "remedy" and "procedure" to be determined exclusively according to the law of the forum. The same identification has been accorded state arbitration statutes and the United States Act making arbitration agreements qualifying thereunder, respectively, irrevocable and enforceable. These statutes have been held to involve matters of remedy and procedure in the respective courts only. The remedies of the state statute have been denied effect as such in the federal courts. The same identification was used by the Supreme Court in sustaining the United States Act when its constitutionality was challenged for its extension into admiralty and maritime jurisdiction.

The want of substance of common law revocability and nonenforceability of arbitration agreements and the expediency of legislative reform by arbitration statutes like the United States Act have been well summarized by Judge Cardozo in the decision sustaining the constitutionality of the New York Arbitration Law. He emphasized that common law revocability and common law non-enforceability of arbitration agreements, in so far as they have been adjudicated in the American jurisdictions, are judge-made law. As the courts so made these rules of procedure before them, so might they undo them and accord irrevocability and other enforce-

${ }^{28} 125$ F.2d 493, 495 (5th Cir. 1942) (italics supplied). The arbitration provision was contained in a contract declared by the court clearly to be one "evidencing a transaction involving commerce." See also, Gatliff Coal Co. v. Cox, 142 F.2d 876 (6th Cir. 1944), in which the Court of Appeals for the Sixth Circuit, although it saw fit to take note of the revocability of the arbitration provision under the law of the state of Kentucky from which the case had been removed to the federal court, declared: "An agreement that all differences arising under a contract shall be submitted to arbitration relates to the law of remedies and the law that governs remedies is the law of the forum. Such a contract, whatever form it may assume, affects in its operation the remedy alone." Id. at 88I (italics supplicd). See also, Pioneer Trust \& Sav. Bank v. Screw Machine Products Co., 73 F. Supp. 578 (E. D. Wis. 1947). 
ment. Some state courts have done so with respect to revocability. ${ }^{29}$ And as the state courts can undo common law revocability and non-enforceability, and state legislatures can require them to do so, without infringing constitutional limitations, it seems clear that the courts of the United States can do likewise, or, in any event, that the Congress can require them to do so with respect to arbitration agreements covering any controversies which otherwise might be litigated in those courts under their established jurisdiction. Judge Cardozo set out the views of the New York Court of Appeals to which we refer as follows: ${ }^{\mathbf{3 0}}$

We think there is no departure from constitutional restrictions in this legislative declaration of the public policy of the state. The ancient rule, with its exceptions and refinements, was criticized by many judges as anomalous and unjust. (D. \& H. C. Co. v. Pa. Coal Co., supra at p. 258; Fudickar v. Guardian Mutual Life Ins. Co., 62 N. Y. 392, 399, U. S. Alphalt Refining Co. v. Trinidad Lake Petroleum Co., 222 Fed. Rep. I006, and cases there cited.) It was followed with frequent protest, in deference to early precedents. Its hold even upon the common law was hesitating and feeble. We are now asked to declare it so imbedded in the very foundations of our jurisprudence and the structure of our courts that nothing less than an amendment of the Constitution is competent to change it. We will not go so far. The judges might have changed the rule themselves if they had abandoned some early precedents, as at times they seemed inclined to do. . . . No one would have suspected that in so doing they were undermining a jurisdiction which the Constitution had charged them with a duty to preserve. Not different is the effect of like changes when wrought by legislation.

It remains to take account of Erie $R$. Co. v. Tompkins. Of course it had not been decided when the United States Act was originally enacted. It was not, therefore, a deterrent at that time to the extension of the Act to arbitration agreements covering controversies arising from sources outside "maritime transactions" or "commerce" but which otherwise might be litigated in the federal courts under their established jurisdiction. We are unable to find anything in the Erie case, or its successors, upon which to base a conclusion that the Congress does not have constitutional power so to extend the Act. We have observed above that prior to the decision in the Erie case the Supreme Court, in Marine Transit Corp. v. Dreyfus, saw fit to reiterate its identification of the New York Arbitration Law as involving a matter of "remedy only" for the New York courts and sustained the application of the United States Act with its remedy of specific performance in admiralty as being within the "general power of the Congress to provide remedies in matters falling within the admiralty jurisdiction of the federal courts, and to regulate their procedure." We believe that this identification is still useful and that it may be relied upon to support the extension of the coverage of the United States Act as we suggest.

20 See supra note 5 .

${ }^{30}$ Berkovitz v. Arbib \& Houlberg, 230 N. Y. 26r, I30 N. E. 288, 292 (I92r) (italics supplied). See also Judge Frank's review of the background of common law revocability and non-enforceability as set forth in Kulukundis Shipping Co. v. Amtorg Trading Co., supra note 3. Compare, Judge Hough in Atlantic Fruit Co. v. Red Cross Line, 5 F.2d 218 (2d Cir. r924). 
We are taught, and have easily followed the teaching of Justice Frankfurter in cases like Guaranty Trust Co. v. York, ${ }^{31}$ that matters of "remedy" or "procedure" and matters of "substance" define no "Great Divide cutting the whole domain of law" and that they (such names and categories) may be put aside in connection with the application of the Erie decision as "abstractions" until at least a specific issue is measured against the purpose of that decision. We also learn from the York case that "the nub of the policy that underlies Erie R. Co.v. Tompkins is that for the same transaction the accident of a suit by a non-resident litigant in a federal court instead of in a State court a block away should not lead to a substantially different result"; that "the intent of that decision was to insure that, in all cases where a federal court is exercising jurisdiction solely because of the diversity of citizenship of the parties, the outcome of the litigation in the federal court should be substantially the same, so far as legal rules determine the outcome of a litigation, as it would be if tried in a State court." And so whether a state statute of limitation is a matter of "substance" or "procedure" is to be judged only "in the aspect that alone is relevant to our problem, namely, does it significantly affect the result of a litigation for a federal court to disregard a law of a State that would be controlling in an action upon the same claim by the same parties in a State court?"

This requirement that the federal court in a diversity case shall duplicate the state court so that the outcome of the litigation in the federal court shall be substantially the same, so far as legal rules determine the outcome of a litigation, is quite remote from the issues of revocability and enforceability of arbitration agreements. Those issues are sufficiently unique and constant to give considerably concrete content to distinctions between matters of "remedy" and "substance" even though, otherwise, those terms in first instances may assume the role of abstractions. If irrevocability and enforceability of the arbitration agreement is determined there will be no litigation in any court and there will be no question of assuring that the outcome of litigation in the federal court will be substantially the same, as far as legal rules determine the outcome, as if it were in the state court. Instead the controversy will be heard and determined by the arbitral board without necessity of following "the law" unless the parties so agree. In other words, the controversy will be heard and determined by the arbitrators serving neither as a federal or state court and free to disregard generally the law of the state which might control litigations as matters of "procedure" in any context or which might determine "substance" in any context. Otherwise stated, "the nub of the policy that underlies Erie R. Co.v. Tompkins" to conform "the law" of the federal court to that of the state court to the extent that the "outcome of the litigation in the federal court should be substantially the same, so far as legal rules determine the outcome of litigation, as it would be if tried in a state court" seems not at all applicable to the determination of issues of revocability and enforceability of arbitration agreements. ${ }^{32}$

${ }^{31} 326$ U. S. 99, 109 (1925) (italics supplied).

${ }^{32} \mathrm{~A}$ fit instance of the applicability of the intent of the Erie decision in conncction with an arbitra- 
Of course, if, in the state court, the arbitration agreement would be revocable and non-enforceable according to common law tradition, the controversy might be litigated there in lieu of arbitration, while, if the United States Act were extended in its coverage of arbitration agreements as we suggest, it could not be litigated in the federal court unless the parties waived or abandoned their arbitration agreement. In such case the federal court would not be able to duplicate "State law or State policy" with respect to the arbitration agreement, nor to hear and decide the controversy covered by the agreement in conformity with the requirements of the Erie case, or otherwise. But we do not understand that the Erie case restricts the power of the Congress so to restrain the power of the federal court to hear and decide such controversies.

Such extension of the Act would constitute a determination by the Congress of its control over the law-making function-jurisdiction to hear and decide-of the federal courts. That jurisdiction would be limited by the extension of the Act. We find nothing in the Erie $R$. Co. case, or elsewhere, that purports to voice constitutional restraint upon the Congress to establish such limitation upon the federal courts in diversity cases or otherwise. And in this connection we are inclined to emphasize that the remedies of stay of trial $(\$ 3)$, order to proceed $(\$ 4)$, and court appointment of arbitrators $(\$ 5)$ are a team of remedies, each auxiliary to the other, designed to accord complete remedy under the arbitration agreement; their distinctions are formal, not substantial, when measured by the declared objective of the Act $(\$ 2) .^{33}$ It should be conceded that there will be preliminary proceedingsmotions-to invoke the remedies of these sections. Issues may then arise as to the making of the arbitration agreement, its coverage of the given controversy, the freedom from default under that agreement of the moving party, default thereunder of the defending party, and other "equitable considerations." The court will then be called upon to hear and determine such issues in order to determine the validity of the claim to the remedy of the given section. Regarding, as we do, the remedy sought as being matter of "remedy only" for the purpose at hand, so do we consider these preliminary proceedings and the hearing and determination of the validity of the claim to the remedy as ancillary to it and as being also matter of "remedy

tion and award will appear as follows. The arbitration was had and award rendered under state law. The arbitration provision did not qualify under the United States Act. The award is challenged in common law proceedings in a federal court, either by defending against its enforcement or by plenary suit to vacate it. Clearly state causes to defeat the award should rule the determination of the validity of the award. See Tejas Development Co. v. McGough Bros., 165 F.2d 276 (5th Cir. I947).

${ }^{33}$ We are not unmindful of the broad language in Angel v. Bullî̀. words are: "The essence of diversity jurisdiction is that a federal court enforces State law and State policy"; that "diversity of jurisdiction must follow State law and policy" (italics supplied). These are the words of Justice Frankfurter, who, again, as in Guaranty Trust Co. v. York, supra, was dealing with the applicability of the "nub of the policy that underlies Erie R. Co. v. Tompkins" which he set out in the York case as quoted above. We do not read the foregoing language of the Justice as intending more than to be disciplinary of the federal courts in their hearing and deciding litigation in diversity cases. We do not read it as intending to indicate constitutional restriction upon the power of the Congress to require the federal courts to deny hearing and judgment by those courts in diversity cases in honor of a pertinent arbitration agreement between the parties. 
only." In short, we believe that the rationale and ruling of the Supreme Court in Marine Transit Corp. v. Dreyfus, may well be relied upon to support the extension of the Act as we suggest. ${ }^{34}$

Relying upon the foregoing considerations, we conclude that, at the time the Act was originally enacted (I925), there was no controlling constitutional limitation upon the Congress requiring the Act to be restricted to arbitration agreements concerning controversies arising out of a "maritime transaction" or out of a contract evidencing a transaction involving "commerce." Probably, however, apprehension over the power of Congress in this connection deterred the extension of its coverage. It could, and should, we believe, have been extended to embrace arbitration agreements covering any other and different controversies over which the courts of the United States otherwise have jurisdiction by the laws of the United States to hear and decide, whether diversity cases or otherwise. We submit that the Erie case does not voice constitutional or other restraint upon the Congress to make such extension of the Act.

It should be noted that the courts of the United States are not, of course, responsible for the limited coverage of the Act. Indeed, they may be expected to administer the Act as it was written by the Congress.

On the other hand, it seems clear that the federal courts are challenged anew to determine whether or not they will adhere to ancient "judicial hostility to arbitration" as to arbitration agreements covering controversies outside the Act which may be brought before them in due course of their jurisdiction. Except with respect to the exclusion of certain contracts of employment as set out at the end of Section I (which is considered in a separate topic below), it is difficult indeed to find in the making of the Act any positive purpose to relegate arbitration agreements outside the Act to traditional revocability and non-enforceability. At the most, it seems, such agreements constitute mere omissions without any implication of positive approval of ancient revocability and non-enforceability. The Act clearly indicated, to the extent of its coverage, a "new orientation," by denying traditional judge-made rules of revocability and non-enforceability of arbitration agreements, and it is difficult to imagine, in the light of the very existence of the Act, how arbitration agreements though outside the Act, may be gauged as against "public policy" just because they are not covered by the Act. The difficulty will be especially great

\footnotetext{
${ }^{34}$ It may be noted in this connection that, although the question of constitutional powcr was not in issue (nor was the Erie case referred to), substantial judicial opinion has been voiced that all of the present sections of the Act providing for enforcement of arbitration provisions may be extended to arbitration provisions in written contracts outside "maritime transactions" and "commerce." This opinion can be accumulated to cover Sections 3,4, 5, and 8 of the Act as indicated herewith. It was voiced after the Erie decision except as otherwise indicated. Judge Goodrich in Donahue v. Susquehanna Collieries Co., infra (\$3); Judge Parker in Agostini Bros. Bldg. Corp. v. United States, infra (\$3), and in International Union United Furniture Workers v. Colonial Hardwood Flooring Co., infra ( $\$ \S_{3}$ and 4 ); Judge Manton in The Gerald A. Fagan, infra note 41 ( $\$ \S_{4}$ and 8 ; before the Erie case). While we doubt, as set forth later, the validity of this opinion, as a matter of interpreting the Act, we note here that no dynamic constitutional restriction upon the power of the Congress so to extend the Act occurred to the judges to cause them to deter or qualify their opinion.
} 
with respect to arbitration agreements which might constitutionally have been brought under the Act when they come into a federal court from a jurisdiction having an arbitration statute of similar pattern to the United States Act, whereby, as respects the agreement, the traditional rules of revocability and non-enforceability would be nullified or when the disputed claim covered by the agreement is a cause arising under a law of the United States. ${ }^{35}$

Of course the "nub of the policy" of the Erie case returns for consideration in this connection in diversity cases. Grant that irrevocability and other enforceability be accorded the given arbitration agreement by state law, must the federal court, otherwise having jurisdiction to hear and decide the controversy, as a diversity case, accord the same consequences to the agreement as would the state court in order to meet the policy of the Erie case? Grant, on the other hand, that common law revocability and non-enforceability would be accorded by the state court, must the federal court, it being a diversity case, follow suit to meet the requirements of the Erie case?

We have been unable, as was Judge Cardozo in Berkovitz v. Arbib and Houlberg, and as was Judge Frank in Kulukundis Shipping Co. v. Amtorg Trading Co., to find any substance for common law revocability and non-enforceability. They thwart the agreement of the parties for no substantial reason. We doubt that the policy intended by the Erie case is expected to control the determination of the issue whether a hearing and trial in the federal court shall be had or whether arbitration shall be had in lieu thereof. We concede, however, that it is somewhat easier, perhaps, to find, notwithstanding the policy of the Erie case, no constitutional limitation of the power of the Congress to extend the coverage of the Act, as we have suggested, than to find the freedom of the federal court in a diversity case to determine whether or not to hear and decide a controversy when it is confronted with the parties' arbitration agreement outside the Act.

Of course, it remains to concede that it may well be deemed beyond the competence and call-of-duty of the federal courts to accord the motion remedies of the Act to arbitration agreements which do not qualify thereunder. The party in $Z$ ip Mfg. Co. v. Pep Mfg. Co. moved for stay under Section 3; it was denied because the court found that the Act did not apply to the arbitration agreement since it was not in a "maritime transaction" nor in a contract involving "commerce." It may be admitted that the court was not called upon to decide more in view of the party's invocation of the statutory remedy. But if the stay had been sought by answer as at common law in reliance on the arbitration agreement, or if the more formal specific performance were sought in plenary suit, or if court appointment of arbitrators were sought in aid of the enforcement of the agreement, it is not clear how these enforcements could plausibly be denied by any reliance placed upon the ancient tra-

${ }^{35}$ As to how this problem may present itself to the courts of the United States, see Zip Mfg. Co. v. Pep Mfg. Co., 44 F.2d I84 (D. Del. I930), (overruled on grounds to be considered in the next topic, see infra note $3^{6}$ ), and Voutrey v. General Baking Co., 39 F. Supp. 974 (E. D. Pa. I94r). Compare, Judge Hough in Atlantic Fruit Co. v. Red Cross Line, 5 F.ad 218 (2d Cir. I924). 
dition that arbitration agreements are against "public policy" as attempts to oust the courts of their jurisdiction.

\section{III}

\section{Whether Or Not Section 3 Is Limited to Arbitration Agreements Covering Controversies Arising Out of "Maritime Transactions" Or Contracts Evidencing a Transaction in "Commerce"}

Section 3, with its catch line, reads as follows:

\section{STAY OF PROCEEDINGS WHERE ISSUE THEREIN REFERABLE TO ARBITRATION}

\$3. If any suit or proceeding be brought in any of the courts of the United States upon any issue referable to arbitration under an agreement in writing for such arbitration, the court in which such suit is pending, upon being satisfied that the issue involved in such suit or proceeding is referable to arbitration under such an agreement, shall on application of one of the parties stay the trial of the action until such arbitration has been had in accordance with the terms of the agreement, providing the applicant for the stay is not in default in proceeding with such arbitration.

As previously indicated, there has been some diversity of view on the question whether the remedy of stay of trial provided in Section 3 is limited to arbitration agreements covering controversies arising out of "maritime transactions" or contracts involving "commerce," or extends to arbitration agreements covering controversies arising out of other and different "transactions" or contracts, which may become the subject of action in the federal courts. Judicial consideration of this question thus far has related to written arbitration provisions to settle by arbitration controversies arising in the future from the contract in which the provision was contained-not as to agreements of submission of existing controversies. More precisely stated, perhaps, the diversity to be reviewed relates to whether or not the scope of Section 3 is limited to arbitration provisions qualifying under Section 2.

The Court of Appeals for the Third Circuit was the first court of appeals to decide this question. It ruled in Donahue $\nu$. Susquehanna Collieries Co. ${ }^{30}$ that Section 3 is not so limited. Part of Judge Goodrich's opinion for the court has been quoted above in the last preceding topic. Notwithstanding some repetition, his opinion on this point will be set forth here in full: ${ }^{\mathbf{3 7}}$

The second question is whether $\$ 3$ of the Act, which provides for a stay of proceedings in a lawsuit until arbitration proceedings have been had, is limited to the contracts and transactions described in $\$ 2$. This is the question on which the parties have expended the bulk of their ammunition. . . .

The title of the Act suggests, though of course it does not compel, the conclusion that the provisions of the statute are applicable to three kinds of things: (I) Contracts, (2)

${ }^{36}{ }_{13} 8$ F.2d 3 (3d Cir. 1943), reversing on this point the decision of the district court, 49 F. Supp. 843 (M. D. Pa. I943); also overruling Zip Mfg. Co. v. Pep Mfg. Co., 44 F.2d r84 (D. Del. 1930).

${ }^{37}{ }_{13} 8$ F.2d at $4^{-6}$ (italics supplied). 
maritime transactions and (3) commerce, interstate and foreign. The first section defines maritime transactions and commerce. Then the second section proceeds to lay down a rule of substantive law regarding the validity of an agreement for arbitration in case of any maritime transaction or a contract evidencing a transaction involving commerce. Congress was here making a rule concerning subject matter within its own constitutional legislative authority. It was not seeking to confer validity to arbitration agreements generally, a matter outside the scope of federal powers. Instead it picked out two important classes of transactions within the federal legislative domain and declared the effect of arbitration clauses in agreements concerned therewith.

Then in $\$ 3$ the statute deals with the conduct of suits in federal courts, again a subject matter of congressional power. The language becomes general: "any suit or proceeding," upon "any issue referable to arbitration under an agreement in writing for such arbitration" are the words. Congress is not limited, in legislating as to law suits in federal courts, to those suits involving matters where the substantive rights of the parties may be controlled by federal legislation. The generality of the language used in the statute does not suggest any self-imposed limitation. Nor do we think that the "congressional approval of arbitration," should be so limited by implication, by a grudging type of construction carried down from the days of judicial hostility to all arbitration agreements. We think it clear that the provisions of $\$ 3$ are not to be limited to the specific instances dealt with in $\$ 2$.

The Court of Appeals for the Fourth Circuit likewise ruled in Agostini Bros. Bldg. Corp. v. United States ${ }^{38}$ that Section 3 is not limited to arbitration agreements in transactions or contracts designated in Section 2. Judge Parker's opinion on this point is of the same general tenor as that of Judge Goodrich in the Donahue case, as follows: ${ }^{39}$

${ }^{38} 142$ F.2d 854 (4th Cir. 1944).

${ }^{30}$ Id. at $855-856$ (italics supplied). Both Judge Goodrich and Judge Parker cited an avowed dictum by Judge Learned Hand in Shanferoke Coal \& Supply Corp. v. Westchester Service Corp., 7o F.2d 297 (2d Cir. 1934) as tending to support their views. Judge Hand had commented in that case that " section 2 defines those contracts which it makes 'valid, irrevocable and enforceable,' and no doubt such alone are within section 4. Krauss Bros. Lumber Co. v. Louis Bossert \& Sons, 62 F.2d roo4 (CCA 2). But it does not follow that section 3 is so circumscribed; the language is: 'If any suit ... be brought . . . upon any issue referable to arbitration under an agreement . . . for such arbitration.' 'Such arbitration' may very well refer back to 'any issue referable to arbitration' and not to section 2. The change in language from section 5 of the New York Arbitration Act, from which, in general, section 3 of the federal act was copied, was plainly deliberate. In the New York act the clause had read, 'under a contract . . . described in section two' and' section 2 of that act was the analogue of section 2 of the federal act ( 9 USCA 52). 'Such arbitration' was very awkward as an equivalent for all that is comprised in section 2 of the federal act, and suggests a broader intent. It is not necessary, however, to decide the point here, because the contract 'involved commerce' as defined by section $x$. " 70 F.2d at $298,299$.

Many other instances of frailties of draftsmanship appear in the Act; but we have difficulty in finding basis in the Act or in its legislative history for Judge Hand's thought that the change of language in Section 3 of the Act from Section 5 of the New York "Act was deliberate and for the purpose indicated by him; we expect that it was more fortuitous than otherwise. And, at all events, Judge Hand's view seems unduly to identify the independence of Section 3 and disassociate it from the rest of the Act (including Section 2), of which it is only a part.

In accord with the foregoing rulings by Judges Goodrich and Parker (outside their circuits) are: Pioneer Trust \& Sav. Bank v. Screw Machine Products Co., 73 F. Supp. 578 (E. D. Wis. I947); Wilson \& Co. v. Fremont Cake \& Meal Co., 77 F. Supp. 364 (D. Neb. 1948).

Expressions of approval, in addition to Judge Learned Hand's, supra, also appear in In re Pahlberg Petition, $x_{3}$ F.2d 968 (2d Cir. 1942); and Lewittes \& Son v. International Union United Furniture Workers, 95 F. Supp. 85 I (S. D. N. X. I95I). 
We see no reason to thus limit the plain meaning of the general language used in section 3. Congress gave its approval to the principle of arbitration by the enactment of the statute (Shanferoke v. Westchester Service Corp., supra, 293 U. S. 449, 453, 55 S. Ct. 3 I3, 79 L. Ed. 583); and it manifestly intended to exercise its full power in furtherance of the principle. The statute was entitled "An Act to make valid and enforceable written provisions and agreements for arbitration of disputes arising out of contracts, maritime transactions, or commerce among the States or Territories or with foreign nations," 43 Stat. 883,9 U. S. C. A. §ז-15. As introduced into Congress, section 2 of the Act provided for the validity and enforceability of arbitration agreements "in any contract or maritime transaction or transaction involving commerce." The Senate Committee struck the word "contract" from the section and rewrote the language in its present form, so as to cover only maritime transactions and transactions involving interstate and foreign commerce. Senate Report No. 536, 68th Congress; Zip Mfg. Co. v. Pep Mfg. Co., D. C., 44 F.2d r84. This was evidently done because it was realized that Congress had no power to legislate with respect to the validity of contracts generally but only as to the validity of those which related to matters subject to its control.

There could be no question, however, as to the power of Congress to exercise the full power attempted by section 3 of the act. Its power to regulate the procedure of the lower federal courts, and even to limit their jurisdiction was well established; and there was no reason why it should not provide in furtherance of the arbitration, which it was seeking to promote, that, where arbitration was provided for by a contract in suit, proceedings in such courts should be stayed until arbitration should be had pursuant to the contract. The power exercised by Congress in section 3 is in no respect dependent upon that exercised in section 2; there was no ambiguity in the language employed in section 3; and there was no reason that we can apprehend why the language used should not be given its normal and ordinary meaning or why it should be held limited by the provisions of section 2 where Congress was exercising a limited power. If it had been intended that the stay provided by section 3 should be limited to the cases where Congress had legislated with respect to the validity of contracts, it would have been easy enough to say so.

The foregoing rulings by the Courts of Appeals of the Third and Fourth Circuits are regarded as of doubtful validity. We believe that the Act invites the reading of its sections into more correlated relationship. While the proponents of arbitration-even those who may not come within Judge Frank's "more enthusiastic" sponsors of the process-will appreciate the "new orientation" as championed by Judges Goodrich and Parker, in their opinions in the foregoing cases, their precise conclusions on the above issue, however, are difficult to support.

This is true for several reasons. We already have made the point that in so far as those rulings are predicated upon an assumption that the Congress had broader or different power to grant the stay remedy of Section 3 than the other enforcement remedies of Sections 4 and 5 , they are weakened because the assumption is ill founded. Again, the language of Section 3 is no more inclusive of what arbitration agreements are embraced therein than the language of Sections 4 or 5 ; Sections 4 and 5 standing by themselves do not purport any more than Section 3 to be tied to controversies arising out of "maritime transactions" or contracts evidencing a transaction involving "commerce." This also is true of Section 8 . If by its language 
Section 3 were plausibly extended, the language of Sections 4 and 5 might be likewise extended. Indeed, Judge Parker appears to have accepted this view in his subsequent opinion in International Union United Furniture Workers v. Colonial Hardwood Flooring Co.40 After noting from the legislative history of the Act that "any contract" was eliminated by the Senate Committee from the original Section 2, he went on to point out that no change had been made limiting in any respect the original language of Sections 3, 4, or the succeeding sections of the Act. Indeed, he concluded that his holding in Agostini Bros. Bldg. Corp. v. United States, to the effect that Section 3 should not be interpreted as limited by the provisions of Section 2, would be equally applicable to Sections 4 and 5. "The reasoning of that decision," he said, "would apply equally to section 4 and the succeeding sections." We understand him to mean in this connection that in so far as generality of language is concerned the language of Section 3 is no more comprehensive than that of Sections 4 and $5 .{ }^{41}$ The courts have been nearly in accord, in so far as they have passed upon the precise issue, that the enforcement remedies of Sections 4 and 5 are limited to arbitration agreements in "maritime transactions" or in contracts involving "commerce" as contemplated in Section 2.42

It will be noted that as this thesis of generality of language (i.e., not being expressly tied up to "maritime transactions," "commerce," or Section 2) is extended from Section 3 to Sections 4, 5, and 8 there will be little, if any, use for Sections I and 2. Quite clearly those sections were to have a more substantial role in the Act.

We have pointed out that Section 2 contains the statement of objective of the Act, namely, to render designated arbitration agreements "valid, irrevocable and enforceable" and that the remedies of Sections 3,4, and 5 are precisely tailored to accomplish, each its part, of that objective by overcoming the precise instances in which common law revocability and non-enforceability are effective. While the stay remedy of Section 3 is formally more negative than the remedies of Sections 4 or 5 , it serves as a positive injunction against one instance of common law revocability in furtherance of the objective broadly set down in Section $2 .^{43}$ In short, the stay

${ }^{10}$ I 68 F.2d 33 (4th Cir. 1948).

"1 We do not gather that Judge Parker sought to impugn his decision in the Agostini Bros. Bldg. Corp. case; nor that he necessarily intended to indicate that he was ready to rule that Sections 4 and 5 (as wcll as Section 3) cover arbitration agreements outside those identified in Section 2.

In The Gerald A. Fagan, 49 F.2d 215 (2d Cir. I93I) views similar to those last quoted from Judge Parker had been advanced by Judge Manton with respect to Section 8 . In a proceeding in admiralty involving Section 8 it was indicated that application for an order to arbitrate might well be granted although the arbitration provision was not in a "maritime transaction" or "commerce" provided it covered a cause justiciable in admiralty. The generality of the language (i.e., freedom from tie-up with "maritime transaction" and "commerce") of both Sections 4 and 8 were cited in this connection, as follows: "From an examination of this act, it will appear that the terms 'maritime transactions' and 'commerce' defined in section $I$ are found again in section $2 \ldots$ Sections 4 and $8 \ldots$ which permit applications to the court, make no reference to these terms." Id. at 217.

"Supra note 12.

13 There has been some tendency to differentiate a stay order under Section 3 from an order to proceed under Section 4. The one, it is suggested, is "merely a stay order of a kind long familiar in common law, equity and admiralty actions," while the latter order "is one for specific performance." Judge Frank emphasized this distinction in the course of his learned opinion in Kulukundis Shipping Co. $\mathrm{v}$. 
remedy of Section 3 is as much subservient to and correlated with the objectives of Section 2 as are the remedies of Sections 4 and 5. The three Sections constitute the group of enforcement remedies provided to effectuate the purpose of the Act as set out in Section 2 and only as the remedies of all of those sections are honored is the purpose of Section 2 best assured. It is clear that the Senate Committee understood the correlation of these remedies and that they were so correlated fully to effectuate the declared objective of Section 2 with respect to arbitration agreements therein

Amtorg Trading Corp., I26 F.2d 978, 987 (2d Cir. 1942). He elaborated the point as follows: "There it is a well recognized distinction between such a stay and specific performance: The first mercly arrests further action by the court itself in the suit until something outside the suit has happened; but the court does not order that it shall be done. The second, through the exercise of discretionary cquity powers, affirmatively orders that some one do (or refrain from doing) some act outside the suit."

Judge Frank also felt that "the same equitable considerations" are not applicable to an application for a stay order under Section 3 as to an application for an order to proceed under Section 4 .

We feel that these distinctions go more to form than to substance and that the stay order is as injunctional (specific performance) in accomplishing one instance of equitable relief as the order to proceed in accomplishing another instance of equitable relief. The stay order means something to the plaintiff, namely, that he shall "refrain from doing"; it is "not merely" an order upon the court that it "arrest further action" nor in rem, as it were, against "the action." The facility of accomplishing and verifying compliance with the order of stay under Section 3 is, of course, more immediate and different, by reason of the court's control over its docket and law-making functions, from the situation in the case of an order to proceed under Section 4. But such differences do not scem controlling, or very significant, in identifying their correlative services under the Act.

And while the "equitable considerations" which should be weighed by the court on an application for a stay under Section 3 may not be identical with those attending an application for an order to procecd under Section 4, they are likely to be very similar in the two cases. Issues (I) as to "the making" of the arbitration agreement, (2) as to its coverage of the controversy in question, (3) as to the qualifications of the arbitration agreement under the Act, (4) as to "the default" of the party who presents the application, (5) as to the readiness and willingness of the applicant to arbitrate, $(6)$ as to the default of the adverse party under the arbitration agreement, (7) as to the authority and duty of the district court to hear and decide these preliminary matters, with references to a jury of certain matters prescribed in the Act, (8) as to the course of conduct of the petitioning party which, as a matter of "cquitable consideration" by the court, may or may not be deemed to constitute "waiver," "abandonment," or undue "playing fast and loose" with litigation and arbitration, and (9) the authority and duty of the court to retain jurisdiction of the cause for granting such other and additional remedy as may be provided by the Act or to which the party may be entitled under law-all seem pertinent alike upon an application for one order as for the other. As the party qualifies his claim for arbitration under the onc Section so will he, in most substantial matters, qualify it under the other. The form, futurity, or personalization of the order is of insubstantial consequence to the parties and the court.

It may be noted in passing that the courts, in cases dealing with appealability, have identified both classes of orders as injunctional. A stay order "is in effect an injunction" and appealable as such. Hudson Lumber Co. v. U. S. Plywood Corp., I8r F.2d 929 (9th Cir. 1950). The Supreme Court has declared that "the special defense setting up the arbitration agreement is an equitable defense or crossbill within the meaning of $\$ 274 \mathrm{~b}$ (Judicial Code); and that the motion for a stay is an application for an interlocutory injunction based on the special defense"; therefore the appcal to the court of appeals from the order of the district court denying the application for stay was proper under $\$ 129$ of the Judicial Code.' Shanferoke Coal \& Supply Co. v. Westchester Service Corp., 293 U. S. 449, 452 (1935). See also Gatliff Coal Co. v. Cox, I42 F.2d 876 (6th Cir. 1947).

Compare the appealability in admiralty of orders to proceed and of stay as ruled in Hildegard Schoenamsgruber v. Hamburg American Line, 294 U. S. 454 (r935). And consult, In re Pahlberg Petition, I3I F.2d 968 (2d Cir. I942); The Sydfold, 25 F. Supp. 662 (S. D. N. Y. 1938). Although beyond the scope of this article, we are prompted to rescrve for future criticism the Supreme Court's identification of injunctional orders under either Section 3,4 , or 8 , even for appealability questions, as "not to be distinguished from an order postponing trial of an action at law to await the report of an auditor." 294 U. S. at 456, 457 (italics supplied). Consult gencrally in this connection, Hyman v. Pottberg's exrs., roI F.2d 262 (2d Cir. I939); Krauss Bros. Lumber Co. v. Louis Bossert \& Sons, Inc., 62 F.2d 1004 (2d Cir. 1933). 
designated. There is no indication in the legislative history of the Act that any one of these remedies (Section 3, for example) was expected to service arbitration agreements outside Section 2.

Said the report of the Senate Committee:

The purpose of the bill is clearly set forth in Section 2, which, as proposed to be amended, reads as follows: [quoting the section as enacted]" (italics supplied).

The report continues with respect to what arbitration agreements the bill (which became the Act) applies and the reason for the remedies therein provided as follows:

The "maritime transactions or contracts," to which the bill will apply are defined in section I. Likewise, the definition of "commerce" in the same section, shows to what contracts in interstate or foreign commerce the bill will be applicable.

It is not contended that agreements to arbitrate have no validity whatever. A party may be liable in an action for damages for the breach of an executory agreement to arbitrate; or, if the agreement has been executed according to its terms and an award made, the appropriate action may be brought at law or in equity to enforce the award. Both maritime transactions and contracts involving interstate commerce are at least valid to this extent.

But it is very old law that the performance of a written agreement to arbitrate would not be enforced in equity, and that if an action at law were brought on the contract containing the agreement to arbitrate, such agreement could not be pleaded in bar of the action; nor would such an agreement be ground for a stay of proceedings until arbitration was had. Further, the agreement was subject to revocation by either of the parties at any time before the award. With this as the state of the law, such agreements were in large part ineffectisl, and the party aggrieved by the refusal of the other party to carry out the arbitration agreement was without adequate remedy. . . .

The bill, while relating to maritime transactions and to contracts in interstate and foreign commerce, follows the lines of the New York arbitration law enacted in rg20, amended in 1921, and sustained by the decision of the Supreme Court of the United States in the matter of the Red Cross Line v. Atlantic Fruit Co., rendered February I8, I924 (italics supplied).

It remains to note the frustrazion, if not futility, in furthering the principle of arbitration under the Act, which may attend arbitration agreements which, by the above rulings, are enforced by stay of trial under Section 3 but are beyond the reach of the remedies of Sections 4 and 5. This consideration also tends, in our opinion, to confirm that the Act was not planned for such consequences. It re-emphasizes the expected correlation and team work of the remedies of the three Sections.

By hypothesis, the arbitration agreement is ourside the statute, except Section 3; stay of trial is granted under Section 3. Unless the feteral courts will forsake in full common law revocability and non-enforceability of such arbitration agreements the effect of the stay can readily be nullified by the plaintiff. Notice of revocation at any time before award can block any further progress toward an arbitral settlement of the controversy under the Act. If the federal courts will deny the validity of revocability (by notice and by action) still the plaintiff may refuse to cooperate in appointing the arbitral board and otherwise refuse to perform the arbitration agree- 
ment. If the federal courts will repudiate common law non-enforceability of such agreements, the defendant, having his stay, could seek a decree of specific performance by plenary suit. It would be necessary to determine by the decree how the arbitration should proceed, whether in accord with the Act, or otherwise. If the federal courts will not accord such enforcement, it may occur to the defendant, if he is still ready and willing to arbitrate, to seek the further enforcement in a state court of a state having an arbitration statute of like general pattern as the United States Act. He will be confronted with the problems of bringing the recalcitrant party within the jurisdiction of that court and qualifying the arbitration agreement under that statute. He might or might not succeed according to the situation of each case. The uncertainties attending the accomplishment of this endeavor can only be imagined, although it may be speculated that the mere fact that the federal court has jurisdiction of the case and that it is pending in that court with the outstanding stay of trial should not bar the defendant from invoking the statutory remedies of the state statute in the state court. ${ }^{44}$ If the federal courts will not fully repudiate common law revocability and non-enforceability and if the defendant cannot bring the plaintiff under a state statute like that of New York, or cannot qualify his arbitration agreement thereunder for its enforcement remedies, his stay in the federal court is nearly futile in progressing the cause to arbitration.

In the meantime the plaintiff who is subject to the stay in the federal court may find it smart for his purposes voluntarily to dismiss his action in the federal court, thereby relieving himself from the stay, and start his litigation anew in a state court where the rules of common law revocability and non-enforceability are in full effect. ${ }^{45}$ Of course, the defendant may be successful in returning the case to a federal court, and so on-all of which will bring the parties no further along toward an arbitral settlement of their controversy.

In view of these considerations-namely-the interrelation, interdependence, and group function of the remedies of Sections 3, 4, and 5 of the Act fully to accomplish the purpose of the Act as set out in Section 2, the identification by the Senate Committee of Section 2 as bearing the purpose of the whole Act as set forth above, and the uncertainties and frustration which will attend the accomplishment of any arbitral settlement if the remedies of Sections 4 and 5 are unavailable-it seems most reasonable to conclude that Section 2 is best construed as determining what arbitration agreements come under Section 3 as well as under the other sections of the Act.

\footnotetext{
44 The views and ruling of the Supreme Court in Red Cross Line v. Atlantic Fruit Co., 264 U. S. $x 09$ (1924), might facilitate favorable inference to this conclusion. But sce, Atlantic Fruit Co. v. Red Cross Line, 5 F.2d 218 (2d Cir. 1924).

${ }^{45}$ Concerning these possibilities, see Fremont Cake \& Meal Co. v. Wilson \& Co., 86 F. Supp. 968 (D. Neb. 1949), in which the plaintiff did just what was suggested. And for the end of the arbitration agreement and arbitration in that case, see 183 F.2d 57 (8th Cir. 1950).
} 
IV

\section{Concerning Arbitration Provisions in Collective Bargaining Agreements}

The first section of the Act excepts or excludes certain "contracts of employment." The Section and its catch line (to reprint them a second time for possible convenience of reference) read as follows:

\section{"MARITIME TRANSACTIONS" AND "COMMERCE" DEFINED; EXCEPTIONS TO OPERATION OF TITLE}

\$r. "Maritime transactions," as herein defined, means charter parties, bills of lading of water carriers, agreements relating to wharfage, supplies furnished vessels or repairs to vessels, collisions, or any other matters in foreign commerce which, if the subject of controversy, would be embraced within admiralty jurisdiction; "commerce," as herein defined, means commerce among the several States or with foreign nations, or in any Territory of the United States or in the District of Columbia, or between any such Territory and another, or between any such Territory and any State or foreign nation, or between the District of Columbia and any State or Territory or foreign nation, but nothing herein contained shall apply to contracts of employment of seamen, railroad employees, or any other slass of workers engaged in foreign or interstate commerce (italics supplied).

Reports by the Congressional Committees are silent as to the reason for this exclusion.

Whatever may have been the controlling reason for it at the time the Act was enacted in 1925 , it is clear that arbitration has gained stature and a significant role since then in the administration of collective bargaining agreements. In approaching the scope and operation of this exception or exclusion we adopt the attitude as first voiced by District Judge McGranery in United Office \& Professional Workers, C.I.O., v. Monumental Life Ins. Co. ${ }^{46}$

Under the national policy favoring the enforcement of collective labor agreements through judicial and quasi-judicial processes rather than through the use of economic force, Labor Management Relations Act $\mathrm{r} 947$, Section $\mathrm{r}(\mathrm{b})$, it is well to interpret the Arbitration Act in such a manner as to encourage the effectuation of that policy, and to avoid "a grudging type of construction carried down from the days of judicial hostility to all arbitration agreements."

Judicial decisions involving this exclusion line up in three diversities and contradictions $:^{47}$

${ }^{10} 88$ F. Supp. 602, 607 (E.D. Pa. 1950); also by District Judge Weinfeld in Lewittes \& Sons *v. United Furniture Workers, 95 F. Supp. 851 (S. D. N. Y. 195I).

${ }^{\star 7}$ Some of the state arbitration statutes of like pattern as that of the United States Act have comparable exclusions as follows: California, Code of Civil Procedure \$I280 (r94I) "provided, however, the provisions of this title shall not apply to contracts pertaining to labor"; Louisiana, REv. STAT. \$9:42I6 (1950) "Nothing in this chapter shall apply to contracts of employment of labor . . "; New Hampshire, REv. LAws, c. $415 \$ I$, p. I724 (I94I) "provided, however, that the provisions of this act shall not apply to collective contracts between employers and employees, or between employers and associations of employees in respect to terms or conditions of employment"; Ohio, GEN. CODE ANN. \$I2I48-I (I938) "The provisions of this act shall not apply to (a) collective or individual contracts between employers and employees in respect to terms or conditions of employment ..."; Oregon, Comp. LAws ANN. $\$ \$ I I-60 I$ (1940) excepts controversies which "... respect ... the terms or conditions of employment under 
(I) The exclusion is from the whole Act, including Section 3.

(2) It does not apply to Section 3 because it is only an exception from the definition of "commerce" in Section $\mathbf{r}$.

(3) Arbitration provisions in collective bargaining agreements are not within the exclusicn because the latter are not "contracts of employment" within the meaning of that term as used therein.

The status of a written provision for arbitration in a collective bargaining agreement under the Act appears to have come to judgment in a court of appeals for the first time in Donahue v. Susquehanna Collieries Co. in the third circuit. ${ }^{48}$ The decision has been reviewed above as it determined the scope of

collective contracts between employers and employees or between employers and associations of employees ..."; Pennsylvania, 5 PA. STAT. ANN. I6I (1930) “. . . except a contract for personal services ..."; Rhode Island, GEN. Laws c. 475 \$I (I-938) "provided, however, that the provisions of this chapter shall not apply to collective contracts between employers and employees, or between employers and associations of employees, in respect to terms or conditions of employment"; WIS. STAT. 298.01 (1949) "the provisions of this chapter shall not apply to contracts between employers and cmployees, or between employers and associations of employees, except as provided in Section II I.10 of the statutes" (Section III.ro refers to arbitrations of labor disputes under the sponsorship of the state employment relations board).

There are no such exclusions in the statutes of the other states of this group, namely, Connecticut, Gen. StAт. \$8I5I et seq. (1949); Hawaii, Rev. Laws, c. $165 \$ 8701$ et seq. (1945); Massachusctts, Gen. Laws, c. 25I, §I et seq. (1948); New Jersey, Stat. ANN. \$2:40 (1939).

The New York Statute of 1920 was amended in 1937 to read as follows: "A provision in a written contract between a labor organization, as defined in subdivision five of section seven hundred one of the labor law, and employer or employers or association or group of employers to settle by arbitration a controversy or controversies thereafter arising between the parties to the contract including but not restricted to controversies dealing with rates of pay, wages, hours of employment or other terms and conditions of employment of any employee or employees of such employer or employers shall likewise be valid, enforceable and irrevocable, save upon such grounds as exist at law or in cquity for the revocation of any contract."

Concerning the situation in Washington, see Sturges and Sturges, Some Confusing Matters Relating to Arbitration in Washington, 25 WAsH. L. Rev. I6 (1950).

${ }^{4}$ According to the report of the case in the District Court (Donahue v. Susquehanna Collicrics Co., 49 F. Supp. 843 (M.D. Pa. 1943)) Donahue brought an action on behalf of himself and other employces of the defendant employer to recover overtime claimed to be due them under the Fair Labor Standards Act. The defendant applied for a stay of trial relying upon Section 3 of the Act. The District Judge reported that the arbitration provision was in "the contract of employment entered into between the defendant and the plaintiff-employees." The application for stay was denied on the ground that, to quote the court, "the employment contract here under consideration does not evidence a 'transaction involving commerce' within the meaning of Section 2. Therefore, if Section 3 is limited in its operation to those arbitration agreements which are defined in Section 2 , the defendant's application must be denicd." The judge held that Section 3 was so limited and denied the stay. This ruling was reversed in the court of appeals on the opinion of Judge Goodrich as reported above. The report of the case in the court of appeals does not disclose any more details as to the agreement containing the arbitration provision. In short, the attention of the court of appeals and Judge Goodrich's opinion scem to have been directed rather exclusively to the issue as to the scope and operation of Section 3 and without regard for the limitation or exception of Section I relating to "contracts of employment." Following the denial of the stay in the district court the company (employer) applied to the district court for an order to arbitrate relying upon Section 4. The application was denied on the same ground that the stay had been denicd. Application of Susquehanna Collieries Co., 49 F. Supp. 845 (M. D. Pa. 1943). In the report of this case it appears that the arbitration provision was contained in a collective bargaining agreement entered into by the United Mine Workers and the Anthracite Operators. The plaintiff employecs were union members and the defendant employer was a member of the Operators. The district judge observed in this second case that "The agreement is limited to the matter of wages and conditions of cmployment in the anthracite coal fields of Pennsylvania," and concluded: "There is nothing in the contract here under consideration to indicate that the employment of the plaintiff and those whom plaintiff represents involves "commerce." Id. at 845,846 . 
Section 3 of the Act. It should be noted, however, that the court of appeals did not give any express consideration to the effect of the foregoing exclusion of Section I. And it does not appear in the report of the case that any point was raised as to whether or not the contract containing the arbitration provision was anything other than a "contract of employment."

The Sixth Circuit Court of Appeals was confronted with a similar case in Gatliff Coal Co. v. Cox ${ }^{49}$ within the year following the decision in the Donahue case. Plaintiff-employee sued defendant-employer to recover wages alleged to be due under the Fair Labor Standards Act and relying upon a collective bargaining agreement between the United Mine Workers and the Appalachian Coal Operators. Plaintiff was a union member and the defendant was a member of the Operators. The suit was initiated in a court of the state of Kentucky. The defendant removed it to the District Court for the District of Kentucky and applied for stay of trial of the suit under Section 3. The application was denied in the district court and the order was affirmed by the court of appeals..$^{50}$

The error assigned against the order of the district court denying the stay was based upon the limitation in Section I. It was contended, in effect, that this provision of Section I did not rule the arbitration provision out of the operation of Section 3. The court of appeals appears to have entertained no doubt that the collective agreement containing the arbitration provision was a "contract of employment." In sustaining the order denying the stay, Judge Hamilton stated the position of the court of appeals as follows: $:^{51}$

It is clear that the exception here in question was deliberately worded by the Congress to exclude from the National Arbitration Act all contracts of employment of workers engaged in interstate commerce. Section 2 of the Act makes valid and irrevocable all arbitration agreements in writing to submit to arbitration future controversies arising out of the contract of which the arbitration agreement was a part. It would be senseless to say that the exclusion from the Act covers the validity of the contract, but excludes the stay provision of Section 3. The reason for the exclusion is applicable to the entire Act. The language of the exclusion "herein contained" is found in the first section of the Act. This section is made up entirely of definitions and exceptions to the operation of the title.

Judge Hamilton further indicated that the court of appeals and Judge Goodrich

40 I 42 F.2d 876 (6th Cir. I944).

to The court of appeals gave some attention to the law of Kentucky ruling common law revocability of arbitration provisions. The court observed in this connection: "The rule prevails in Kentucky that parties may not by contract deprive themselves of the right to resort to courts for the settlement of their controversies." Id. at $88 \mathrm{I}$.

It went further to say: "It is our duty to expound, not to make the law of the State." Ibid.

It seems clear that the law of Kentucky relating to the revocability or non-enforceability of arbitration agreements was not pertinent after the removal of the case to the district court. And the court of appeals also concluded as much in another part of its opinion in this case (in close juxtaposition with the foregoing part of its opinion), as follows: "An agreement that all differences arising under a contract shall be submitted to arbitration relates to the law of remedies and the law that governs remedies is the law of the forum. Such a contract, whatever form it may assume, affects in its operation the remedy alonc. Red Cross Line v. Atlantic Fruit Co. 264 U. S. I09, II9, 44 S. Ct. 274,68 L. Ed. 582." Ibid.

${ }^{62}$ Id. at 882. See also, Delaware \& Hudson R. Corp. v. Williams, I29 F.2d II (7th Cir. I942). 
in the Donahue case may have overlooked the exclusion of Section r, or, "if there be implicit in the court's decision a conclusion that the Arbitration Act is applicable to employment contracts, we find ourselves in disagreement." 52

Thus far we have no judicial determination of the question whether an arbitration provision in a collective bargaining agreement is in a "contract of employment" as the term is used in the limitation of Section I. We do have Judge Goodrich's opinion in the Donahue case that Section 3 is not limited to arbitration provisions in transactions or contracts designated in Section 2, and that ruling was made with respect to an arbitration provision in what both the district judge and Judge Goodrich recognized as a "contract of employment." In the Gatliff Coal Co. case the Court of Appeals for the Sixth Circuit expressly recognized the contract containing the arbitration provision as a "contract of employment" and ruled that the arbitration therein was excepted from the whole Act, including, of course, Section 3.

The general question came back to the Court of Appeals for the Third Circuit in I945 in Watkins v. Hudson Coal Co. ${ }^{53}$

Employees sued their employer in the district court on like cause as in the Donahue case and the employer applied for an order to stay the trial and also for an order to arbitrate. The defendant based its applications upon arbitration provisions in a collective bargaining agreement between the United Mine Workers and the Anthracite Operators and upon Sections 3 and 4 of the Act. The District Court for the Middle District of Pennsylvania ${ }^{54}$ (being within the third circuit) granted the stay under Section 3 on the ground that the decision in the Donahue case was controlling. It denied the application under Section 4 for the order to arbitrate on the ground that the power of the court "to grant the affirmative relief requested is limited to those cases over which the court would have jurisdiction under the judicial code at law, in equity, or in admiralty. This is not such a case. ..." The court of appeals modified and affirmed as modified the order of stay and affirmed the order denying the application to arbitrate. Judge Goodrich gave the majority ruling; Judge McAllister dissented. Said Judge Goodrich: ${ }^{.6}$

We have already answered that question [as to the scope of Section 3] in Donahue v. Susquehanna Collieries Co. 1943, r38 F.2d 3, r49 ALR 27r, and the District Court followed that decision in making the order which it did. Our analysis of the problem involved has found support in a decision by the Fourth Circuit in Agostini Bros. Bldg. Corp. v. United States, 1944, 142 F.2d 854. The Sixth Circuit has doubted the correctness of our result. Gatliff Coal Co. v. Cox, 1944, I42 F.2d 876 .

With further reference to the decision in the Gatliff Coal Co. case holding that

¿2 Ibid.

${ }^{53}$ I5 F.2d 31 I (3d Cir. 1945)., cert. denied, 327 U. S. 777 (1946).

54 F. Supp. 953 (M. D. Pa. 1944).

${ }^{55}$ Id. at 958 .

${ }^{60}$ I5I F.2d 311,320 . In a footnote Judge Goodrich made mention of the fact that the decision in the Agostini Bros. case came down on June 2, 1944, and in the Gatliff case on June 1, 1944. "Ob. viously," he said, "neither had the benefit of the consideration of the question by the other." 
the limitation in Section I ruled the whole Act, including Section 3, Judge Goodrich observed as follows : ${ }^{\mathbf{5 7}}$

We think the criticism made by our colleagues in the Sixth Circuit is not convincing. While it is true that in defining commerce in Section I contracts of employment of specified types of employees were excluded, it should be noted that this exclusion was only in the definition of commerce in that section. Section 3 of the statute does not use the term commerce. We do not think that the limitation in the definition in Section I should be applied as an over-all limitation elsewhere to the section where the defined term is not used. We, therefore, adhere to the Donahue decision and with increased confidence because of its emphatic approval by the Fourth Circuit in the case just cited. [Referring to the Agostini Bros. case, with opinion by Judge Parker.]

Judge McAllister did not agree with Judge Goodrich on the limited scope given to the exclusion of employment contracts in Section I. He felt that the arbitration provision in the contract before the court was excepted from the whole Act, including Section 3. "I believe," he said, "that it is so excepted, because it is a contract of employment of a class of workers engaged in interstate commerce."5s

Referring to Section I, he observed ${ }^{59}$

The foregoing section is concerned with definitions of "maritime transactions," and "commerce," and with an enumeration of certain contracts of employment which are excepted from the application of the section or from the application of the entire Act.... In the prevailing opinion it is held that, in defining commerce in Section $I$, contracts of employment of specified types of employees were excluded, but that such exclusion was only in the definition of "commerce" in that section and that the limitation in the definition in Section I should not be applied as an over-all limitation where the defined term is not used.

Viewing the problem from a somewhat different aspect, however, it seems to me that it should be said that the contract in question was one of a class, excepted from the operation of the Act, by virtue of the statutory language used in Section I, wherein it is said that "nothing herein contained shall apply to the contracts of employment of . . . any ... . class of workers engaged in ... interstate commerce." To construe this language as excepting the designated classes of contracts of employment merely from the operation of Section $I$, rather than construing it as excepting such contracts from the operation of all of the provisions of the statute in question, appears to me untenable. The language of exclusion is found in the first section of the Act, which is composed entirely of definitions and exceptions. It is not used with any of the substantive provisions of the statute, which are set forth in the succeeding sections of the Act. Unless the excepting language applies to the entire statute, it seems to me rather meaningless. I am unable to read the phrase, "but nothing herein contained shall apply to contracts of employment of . . . any ... class of workers engaged in . . . interstate commerce," as a part of the definition of commerce. Rather I feel that the language used in Section I relating to exceptions, is to be understood as referring to the entire statute, instead of merely to the first section.

The general problem was soon to come before the Court of Appeals for the Fourth Circuit and Judge Parker. It did so in 1948 in International Union United

${ }^{57} I d$. at $320-321$ (italics supplied).

${ }^{68}$ Id. at 321 .

${ }^{\text {to Ibid. }}$ 
Furniture Workers v. Colonial Hardwood Flooring Company. ${ }^{60}$ The case was as follows: The employer sued the union of its employees for damages for alleged breach of their collective bargaining agreement by calling a strike contrary to the terms of the agreement. The union applied for a stay under Section 3 of the Act. The motion was denied in the district court. The ruling was based upon two grounds: (I) the arbitration provision did not embrace the controversy in issue-i.e., the company's claim for damages for breach of the no-strike provisions in the collective agreement, and (2) the Arbitration Act was not applicable because it was a controversy relating to the employment of workers engaged in interstate commerce. The court of appeals sustained the district court on both grounds.

Judge Parker was unable to go along with Judge Goodrich's ruling in the Watkins case; instead he sided with the Court of Appeals of the Sixth Circuit in the Gatliff Coal Co. case and with the foregoing dissenting opinion of Judge McAllister in the Watkins case. Said Judge Parker: ${ }^{01}$

It is perfectly clear, we think, that it was the intention of Congress to exclude contracts of employment from the operation of all of these provisions [of the Act]. Congress was steering clear of compulsory arbitration of labor disputes; and unless the excepting clause which we have italicized is applied to the entire Act, and not confined to the first section, section 4 would give the court power to force arbitration in any agreement providing for arbitration where there is jurisdiction because of diversity of citizenship or other reasons. Of course, if the excepting clause applies to section 4, it applies also to section 3; for the only alternative to applying it to the entire Act is to limit it to section $\mathrm{r}$. The effect of limiting the excepting clause to section I would be merely to exclude employment contracts from maritime transactions and transactions in commerce as defined in the Act, so that these would not come within the arbitration agreements made valid and enforceable by section 2, but would leave them, if otherwise valid, to be enforced under the provisions of section 4, the provisions of which are not limited to maritime transactions or transactions in commerce.

After referring to his opinion and ruling in the Agostini Bros. case as determining "that Section 3 of the Act should not be interpreted as limited by the provisions of Section 2," Judge Parker continued: ${ }^{62}$

There is nothing in this, however, to justify the holding that the exclusion clause should not apply to the entire Act and remove employment contracts from the ambit of its provisions, as originally intended.

He then turned to the Donahue and Watkins cases in the third circuit before Judge Goodrich. He observed:3 "We have given careful consideration" to those cases. And

In the first of these cases [Donahue] no reference was made to the excepting clause contained in the statute and the sole question decided was whether the stay provided by paragraph [sic] 3 of the Act was limited to the contracts described in paragraph [sic] . two. We thoroughly agree with what was said by the Third Circuit on this question and

${ }^{60} 168$ F.2d 33 (4th Cir. 1948).

${ }^{62} 1 d$. at 37 .
${ }^{01}$ Id. at 36-37.

${ }^{83}$ Id. at 38 (italics supplicd). 
we quoted at length from its opinion in our decision in the Agostini case, supra. The second case merely followed the first, citing our decision, with the additional statement that limitation in the first section should not be applied to the entire act. Judge McAllister dissented from this conclusion, adopting the view followed in the Sixth Circuit [Gatliff case]. This is the first time that we have had occasion to consider the effect of the excepting clause, and with all respect to the able court whose decision we followed in holding the third section of the act not limited to the contracts covered by the second, we cannot but think that the excepting clause contained in the defining section of the act was intended to apply to the entire act and to except a contract such as that before us from all provisions of the act.

So much for some of the diversity and contradiction in the law of the Act in the Courts of Appeals of the Third, Fourth, and Sixth Circuits relating to the effect of the limitation of certain "contracts of employment" in Section I. So far we have no issue raised, nor determination made, as to whether arbitration provisions in collective bargaining agreements are in "contracts of employment" within the foregoing exclusion of Section $\mathrm{r}$.

In I950 District Judge McGranery in the District Court for the Eastern District of Pennsylvania (within the third circuit) and District Judge Weinfeld in the District Court for the Southern District of New York in I95I ruled that collective bargaining agreements are not "contracts of employment" within the meaning of that term in Section $I$.

In United Office \& Professional Workers, C.I.O., v. Monumental Life Ins. Co., ${ }^{64}$ Judge McGranery recognized that the decisions in the Donahue and Watkins cases: were controlling and granted a stay under Section 3 of a declaratory judgment proceeding brought by the company (employer) against the union to determine whether or not the company was obligated by the terms of their collective bargaining agreement to discharge certain employees.

The judge also granted the union's petition based on Section 4 for an order against the company to arbitrate. This order was entered over objection by the company that the only arbitration agreements enforceable under Section 4 are those covered in Section 2, that Section 2 covers provisions for arbitration in "maritime transactions" and in contracts involving "commerce," and that, since (relying upon Judge Goodrich's opinion in the Watkins case) the contracts of employment designated in Section I are excepted from "commerce," the arbitration provision in the collective bargaining agreement in this case was not enforceable under Section 4 .

The judge concluded that the Third Circuit Court of Appeals had not passed "directly on this issue" but suggested that Judge Goodrich might be influenced by a part of Judge Parker's opinion in the International Union United Furniture Workers v. Colonial Hardwood Flooring Co. case to hold that the remedy of Section 4 is not limited by the definition of "commerce" of Section I. Said Judge McGranery in this connection: ${ }^{65}$

0488 F. Supp. 602 (E. D. Pa. 1950).

${ }^{\circ 5}$ Id. at $605-606$. 
The Court of Appeals for the Third Circuit has not passed directly on this issue, although, as pointed out by the Court of Appeals for the Fourth Circuit in International Union United Furniture Workers v. Calonial Hardwood Flooring Co., supra, r68 F.2d at pages 36-37, under the Third Circuit's interpretation of Section 3 in the Donahue and Watkins cases, supra, it is possible to interpret Section 4 as being unlimited by the commerce definition of Section I, with its excepting clause.

By like combination of the cases, and relying again upon Judge Parker's opinion in the International Union United Furniture Workers case, the same conclusion might be reached with respect to Sections 5 and 8 of the Act. This would render the "commerce" definition of Section $\mathrm{I}$, with its excepting clause, functus officio for all remedies for enforcement of arbitration provisions under the Act (Sections 3, 4, and 5) regardless of Section 2.

Judge McGranery concluded, however, that regardless of the views of the court of appeals in the foregoing cases as to the scope of the exclusion of the designated "contracts of employment" in Section I (whether from the definition of "commerce" or from the entire Act), the determination of the issue was not required in the case before the court. He held that the collective bargaining agreement between the union and the company was not a "contract of employment" and was, therefore, not within the limitation provision of Section $\mathrm{r}$. The judge relied in this connection upon a portion of the opinion of Justice Jackson in J. I. Case Co. ข. National Labor Relations Board ${ }^{60}$ wherein the Justice identified, for the purpose at hand, a collective bargaining agreement entered into between an employer and representatives of a unit of his employees, usually a union, as "an accord as to terms which will govern hiring and work and pay"; that it results in what is frequently called a "trade agreement, rather than in a contract of employment"; and that individual hirings take place under, and are subsidiary to, "the terms of the trade agreement." "67

Judge McGranery further relied upon the carefully considered opinion and decision by the Supreme Court of California in Levy v. Superior Court ${ }^{68}$ in which that court held that an arbitration provision in a collective bargaining agreement between employer and union did not fall within the provision of Section $\mathrm{I}$ of the California arbitration statute which excludes arbitration provisions in contracts "pertaining to labor."

Judge McGranery also was critical of Judge Parker's opinion in the United Furniture Workers case where he indicated that by the exclusion of the contracts of employment designated in Section I Congress intended to steer clear of "compulsory arbitration" of labor disputes. Said Judge McGranery: $:^{60}$

This Court considers, however, that the enactment of a law by the Congress providing for the enforcement of an arbitration contract "voluntarily and solemnly entered into"

${ }^{8 B} 32$ U. S. 332 (1944).

${ }^{87}$ Id. at 335,336 .

${ }^{68}$ I5 Cal. 2d 692, x04 P.2d 770, 774 (1940).

${ }^{\circ 0}$ United Office and Professional Workers of America, C.I.O., v. Monumental Life Ins. Co., 88 F. Supp. 602, 606 (E. D. Pa. I950). 
[quoting from Senate Committee Report 536] between an employer and a union is no more objectionable than any other provision for the specific enforcement of contracts, nor does it in any way approach compulsory arbitration. It is logical to conclude that the Congress was avoiding the specific enforcement of contracts for personal services.

Judge McGranery did not determine whether or not the given collective bargaining agreement involved "commerce." Granting his ruling that the collective bargaining agreement is not a "contract of employment" under the exclusion in Section $\mathbf{I}$, can an arbitration provision in the collective bargaining agreement be enforced under Sections 4 or 5 if it is not in a "maritime transaction" or in a contract involving "commerce"? As reported above, the Judge indicated that, with the Donahue and Watkins cases and Judge Parker's opinion in the United Furniture Workers case, it might be enforced under those Sections.

It remains to note the decision of District Judge Weinfeld in Lewittes \& Sons $v$. United Furniture Workers in $195 x^{70}$ Being in the second circuit the rulings in the Donahue and Watkins cases by Judge Goodrich, in the Agostini Bros. Co. and United Furniture Workers cases by Judge Parker, and that in the Gatliff Coal Co. case by Judge Hamilton were not binding upon the court. The employer sued the union for damages for alleged breach of the no-strike provision in their collective bargaining agreement as did the employer in the United Furniture Workers case. The union moved for stay of trial relying on Section 3 of the Act. Judge Weinfeld noted that "no relief is sought under Section 4 to compel the parties to proceed to arbitration."71 He granted the stay. He sided with Judge McGranery and held that the collective bargaining agreement was not a "contract of employment" within the exclusion in Section $r$. One of the two grounds upon which the plaintiff-employer resisted the application for the stay was that the exclusion in Section $I$ controlled Section 3. The judge reviewed the decisions in the Gatliff Coal Co., United Furniture Workers, and Watkins cases on the question whether the exclusion in Section I "is applicable only to those sections of the Act in which 'commerce' appears or whether it applies to the entire Act, including Section 3 which makes no mention of "commerce." "72 While observing that the conclusion on this question "is not dispositive of the motion for a stay of the pending action" because the collective bargaining agreement is not a "contract of employment" under Section I, he found "more convincing" the dissenting opinion of Judge McAllister in the Watkins case and the ruling in the Gatliff Coal Co. case, namely, that the exclusion applies to the entire Act, including Section 3. "The placing of the exception," he said, "is "in the definition section demonstrates legislative intent that the exception is applicable to the entire Act and not merely to some sections thereof. Moreover, the caption to Section I reads: '. . . exceptions to operation of title' (italics by the Court)-further indication that the exception was meant to apply to the entire Act"; and so it should

\footnotetext{
${ }^{80} 95$ F. Supp. 85I (S. D. N. Y. 195I).

7x Id. at 853 .

${ }^{72} I d$, at 854 .

${ }^{73} \mathrm{Id}$. at 855 .
} 
be deemed to exclude "contracts of employment of workers engaged in commerce from the scope of Section 3."

Judge Weinfeld also observed that the question as to the scope of the exclusion in Section I had not been determined in the second circuit, but that the court of appeals for that circuit "suggested" in Shirley-Herman Co. v. International Hod Carriers" "that contracts of employment in interstate commerce are excluded from the Act, or in other words, that the exception applies to the entire Act."

As in the case of Judge McGranery's granting the union's application under Section 4 in the United Office \& Professional Workers case, so with respect to Judge Weinfeld's grant of stay under Section 3 , it does not appear that precise ruling was intended on the question whether the collective bargaining agreement containing the arbitration provision (granting the agreement is not a "contract of employment" under the exclusion in Section I) must constitute, or be contained in a "maritime transaction" or in "a contract evidencing a transaction involving commerce" under Section 2. He did, however, before reporting his conclusion upon the effect of the exclusion in Section I (as being from the whole Act) and its relation to Section 3, declare that "the Court must necessarily consider the interrelation of Sections 2 and 3." "The question thus arises," he said, "whether, despite the broad language of Section 3, the power to grant a stay is restricted only to such arbitration agreements as are made valid by Section 2, that is those involving 'maritime' or 'commerce' transactions." He concluded in this connection that "It is clear that Section 3 is not limited by the provisions of Section 2." Perhaps it may be concluded from this that Judge Weinfeld intended to hold, or at least to indicate his belief that it is not necessary that the collective bargaining agreement constitute or be contained in a "maritime transaction" or in a "contract evidencing a transaction in commerce" to sustain stay of trial of a suit brought in disregard of the arbitration provision therein.

It remains to read how the general problem returned to the Court of Appeals of the Third Circuit in $195 \mathrm{I}$ in Amalgamated Ass'n etc. v. Pennsylvania Greyhound Lines $^{\text {To }}$ and how the court handled it. Judge Goodrich did not sit on the case. Judge Hastie wrote the unanimous opinion of the court.

It was held that an application for an order to arbitrate brought by a union against the company based upon an arbitration provision in their written collective bargaining agreement and Section 4 of the Act should be denied. The company had moved to dismiss the application on the ground that the court had no jurisdiction under the Act to grant it. This motion was granted in the court below. The application disclosed diversity of citizenship of the parties and that the matter in controversy exceeded $\$ 3,000$. In holding that the application was properly dismissed the court abandoned the view which the court took in the Donahue and Watkins cases that the exclusion of the designated contracts of employment in Section I was a subtraction only from "commerce" as defined in that Section. It

${ }^{74}$ 182 F.2d 806 (2d Cir. 1950). $\quad{ }^{75} 95$ F. Supp. at 855.

${ }^{70}$ r92 F.2d 310 (3d Cir. 195I), and see 193 F.2d 327 (3d Cir. 1952). 
ruled that the exclusion should be judged as effective with respect to the whole Act. It sided with the Gatliff Coal Co. and United Furniture Workers decisions on the point. Secondly, it ruled the collective bargaining agreement to be a contract of employment (and the employees being engaged in interstate commerce) within the exclusion in Section $\mathrm{r}$. No reference was made in this connection to the decisions by Judges McGranery and Weinfeld.7

The decision upon the first point was based upon the proposition that the catch line above Section I was added in the I947 re-enactment of the Act. After calling attention to the foregoing opposing views of the courts of appeals on the scope of the exclusion, Judge Hastie announced the ruling as follows: ${ }^{78}$

With the Courts of Appeals thus divided on the construction of the exception, Congress, in 1947, reenacted and codified the Arbitration Act as Title 9 of the United States Code. The text was not changed. But the catch line which the compilers of the United States Code had inserted at the beginning of Section $I$ of the Arbitration Act when it was included as Section $x$ in Title 9 of the Code, and which had not appeared in the original Act, ${ }^{79}$ was now "enacted into positive law" as follows: " $\$$ I "Maritime transactions' and 'commerce' defined; exceptions to operation of title."

This history considered, the company contends and the district court apparently decided that by the newly enacted catch line to Section I, Congress resolved the disagreement between circuits and approved the construction theretofore placed on the excepting language by the 6th Circuit. Moreover, since the codification the Court of Appeals for the $4^{\text {th }}$ Circuit has adopted the construction of the 6th Circuit, although upon reasoning which indicates that it would have done so even under the original enactment. International Union United Furniture Workers v. Colonial Hardwood Flooring Co., 4 Cir., I948, r68 F.2d 33 .

Unquestionably, the original text was ambiguous. Enacting a catch line rather than amending the text is an unusual method of removing ambiguity in a text. But in this case we think the enactment serves that purpose. The only alternative would be to declare that the catch line is without significance. ...

Accordingly, we conclude that our earlier construction of the exception is inconsistent with the intention of Congress as subsequently made manifest.... It follows that arbitration of a dispute arising out of a "contract of employment" cannot be required under that Title.

The novelty of the effect given this catch line aside, we conclude that the court cannot be supported in its conclusion as to the significance given by it to the line without noting that it was in the Code, r 940 edition. Furthermore, the legislative

${ }^{77}$ The case was argued October 2, 1951. Judge McGranery's opinion was filed February 4, I950; Judge Weinfeld's opinion March 1 , r95I.

${ }_{78} 192$ F.2d at 3 12-313.

70 The original Act did have the following catch lines dispersed from top to bottom of Section I on its right-hand margin in the Statutes (43 Stat. Ch. 213, p. 883) as follows: "United States Arbitration Act." "Definitions." "Maritime transactions." "Commerce." "Not applicable to employment contracts of workers" (italics supplied).

But more important still, Section I of Title 9 of the U. S. Code, I940 Edition, carried the same, identical catch line. See supra note $\mathrm{I}$. Judge Hamilton appears to have recognized in the Gatliff Coal Co. case, stupra note 49 (decided in 1944), that the exception was from the operation of "the title." See his opinion as quoted stipra, p. 607 . 
history repeatedly discloses that it was intended that there should be no change in the original Act. ${ }^{80}$

In holding that collective bargaining agreements between an employer and a union of its employees were "contracts of employment" within that term as used in the exclusion in Section I, the court pointed out that Justice Jackson's opinion in J. I. Case Co. v. National Labor Relations Board, was identifying collective bargaining agreements for a different purpose from that involved here; that, accordingly, it was not controlling here; nor, indeed, persuasive. Also, that to apply the Arbitration Act to arbitration provisions in collective bargaining agreements, would entail undesired interference of the federal bench in the settlement of labor disputes among the classes of workers covered by the exclusion in Section $x .^{81}$ Said the court in this connection: $:^{22}$

Widespread dissatisfaction with compulson from the federal bench in labor disputes during the era in which the statute was passed ${ }^{83}$ was paralleled by the existence of administrative rather than judicial machinery for settlement of labor disputes in the case of both "classes of workers" specified in Section I. . . . For Congress to have included in the Arbitration Act judicial intervention in the arbitration of disputes about collective bargaining involving these two classes would have created pointless friction in an already sensitive area as well as wasteful duplication. It is reasonable, therefore, to believe that the avoidance of an undesirable consequence in the field of collective bargaining was a principal purpose of excepting contracts of employment from the Act. In these circumstances the phrase "contracts of employment" should be construed to include collective bargaining agreements. Finally, while the situation existing in cases of seamen and railroad employees clarifies the meaning of the statute its terms also include "any other classes of workers" in interstate commerce. Such a class is involved here.

${ }^{80}$ The purpose of the 1947 legislation was declared to be to "Codify and Enact into Positive Law Title 9 of the United States Code, Entilled Arbitration." It was pointed out by Mr. Robinson who introduced the bill (HR. 2084) into the House and by Assistant Attorney General MeGregor in a letter to the Senate Committee on the Judiciary (SR 664, 8oth Congress) that, while the U. S. Code was extremely valuable, its usefulness "was somewhat circumscribed by the fact that it has never been enacted into law." Five separate titles of the Code, including Title 9, werc submitted to the Congrcss at the same time and were severally passed as separate titles to give them the status of "positive law." (Compare the Preface to The Code of the Laws, reported supra note r.)

During debate on these titles in the House (there was no debate in the Senate), Mr. Robinson was repeatedly questioned whether any change in existing law was being made by the five bills. In reply Mr. Robinson recurringly answered: "I understand there is no change whatsoever in the law as it is written on the books today." And when referring specifically to the cnactment of Title 9, Mr. Robinson answered: "This bill makes no change in existing law." 93 CoNG. R'Ec. 5029, 5043 (1947).

It is equally clear from this legislative history that the 1947 enactment involved no intent of the Congress to resolve the conflict in the circuit courts over the operation of the exclusion of the "contracts of employment" in Section I. As "no change" in the existing law was intended, so was no conflict in its application resolved.

81 This question whether collective bargaining agreements are included in "contracts of employment" was deemed open in the third circuit. Said the court in this connection: "Decison that such inclusion was intended is necessarily implicit in Gatliff Coal Co. v. Cox, supra, and Intcrnational Union United Furniture Workers v. Colonial Hardwood Flooring Co., stipra. We did not have occasion to decide the issue in Donahue v. Susquehanna Collieries Co. and Watkins v. Hudson Coal Co. cases, supra." 192 F.2d at 3 I3.

${ }^{82}$ I92 F.2d at 313-3r4. Compare re "compulsion from the federal bench" under the Federal Railway Labor Act, Delaware \& Hudson R. Corp. v. Williams, I29 F.2d II (7th Cir. I942).

${ }^{83} \mathrm{~A}$ footnote at this point by the court sets forth that: "The familiar Norris LaGuardia Act, 47 Stat. 70 (1932), 29 U. S. C. A. \$IOI, was the national legislative culmination of this dissatisfaction." 
These contradictions and uncertainties as to the law of the Act in the different circuits are manifest warnings to employers and unions who may contemplate the aid of the United States Arbitration Act in connection with arbitration provisions in their collective bargaining agreements. They will find it expedient to consider whether in a given case it may best serve their purposes to stipulate their arbitration provisions out of the United States Act until a more uniform judicial administration of it is determined.

The review of the foregoing cases indicates that part of this confusion could be obviated were Section 3 construed in deference to Section 2 which is the key section of the Act in declaring the purpose of the Act as to the arbitration agreements qualifying thereunder. The courts, if they will, can readily overcome their overextension of the coverage of Section 3 and accord it its correlative function with Sections 4 and 5 in accomplishing the declared purpose of the Act as set down in Section 2.

It likewise lies with the courts to get together in respect to the function and content of the limitation of Section I relating to the designated "contracts of employment." Once Section 3 (as well as Sections 4 and 5) is properly correlated with Section 2 it will be immaterial whether the exclusion in Section I is subtracted from "commerce" in Section I or from the whole Act. As soon as the limitation in Section I is subtracted, by either device of construction, from Section 2, it will take the arbitration provisions in the designated contracts of employment out of the declared purpose of that Section and outside Sections 3, 4, 5 and their remedies.

Shall the content of the exclusion of Section I be broadly or narrowly construed? Shall collective bargaining agreements between an employer and a union of employees who are seamen, railroad employees, or any other class of workers engaged in foreign or interstate commerce, be identified as "contracts of employment" of those seamen, railroad employees, or other class of workers engaged in foreign or interstate commerce?

In considering these questions it is of dubious aid to accept Judge Parker's suggestion as voiced in the United Furniture Workers case, that the Congress "was steering clear of compulsory arbitration of labor disputes." The term "compulsory arbitration" is quite remote from the arbitral process predicated upon an agreement of the parties to arbitrate their controversies before arbitrators whom they shall appoint. ${ }^{84}$ It is equally unfortunate to analogize the issue of making irrevocable and specifically enforceable arbitration provisions in contracts of employment to the issue of specific performance of employment contracts themselves-which the courts are reluctant to grant. To accord irrevocability and specific enforceability to arbitration provisions in such contracts does not involve specific performance of the employment contract either on the part of the employer as to hiring or as to the employee as to working.

s4 Concerning the identity of "compulsory arbitration," see Wolff Packing Co. v. Industrial Court, 267 U. S. 552 (rg24); Van Riper v. Traffic Tel. Workers' Fed. of New Jersey, 2 N. J. 335, 66 A.2d 6 r6 (1949); New Jersey Bell Tel. Co. v. Communications Workers, 5 N. J. 354, 75 A.2d 72I (I950). 
Only when an award is rendered which requires the employer to hire or the employee to work will an issue of specific performance of the employment contract emerge and then may the courts readily and properly exercise their equitable discretion to refuse specific enforcement of the award.

When the United States Act was enacted in 1925 labor unions and employer groups had varying views as to the feasibility of arbitration of labor controversies. Some favored the enactment of a state arbitration statute like the New York Arbitration Law of I920; some did not. Sometimes one or the other, or both groups, entered no appearance for or against a pending bill looking to such an act. The New York law of xgzo contained no such limitation as Section I of the United States Act. Some of the other state arbitration statutes contain some such limitation; others do not, as pointed out supra note 47. In short, when the United States Act was enacted there was no general, nor national, consensus among either labor unions or employer groups for or against an arbitration statute like it being made applicable or inapplicable to employment contracts or to collective contracts between an employer and a union of his employees. Indeed, the principal impetus for these earlier arbitration statutes was to facilitate "commercial arbitration" (i.e., the arbitration of controversies arising out of general commercial contracts). It also will be recalled that when the United States Act became law the modern collective bargaining agreement had not gained its present identity or legal status and had not come to embrace the functions which attend it today in the field of industrial relations. By the same token the individual's "employment contract" had not become so subordinated to the general agreement.

Absent more driving, positive background to give the limitation of Section I a comprehensive prohibitive role one finds it reasonable to accept Judge McGranery's observations upon the development of national policy favoring the enforcement of collective bargaining agreements through judicial and quasi-judicial process rather than by economic force, and that policy will be best served by according arbitration provisions therein recognition under the Act if they otherwise qualify under the Act, including Section 2.

It remains to note these further considerations concerning the foregoing exclusion in Section $x$. ( $($ ) It does not cover "contracts of employment" of all employees-instead, it names only "seamen, railroad employees, or any other class of workers engaged in foreign or interstate commerce" (italics supplied). Absent the involvement of employees designated in the exclusion there is no occasion to determine the scope or operation of the exclusion as such. (2) Granting that a collective bargaining agreement between an employer and a union of his employees who are of one of the foregoing classes ("seamen, railroad employees, or any other class of workers engaged in foreign or interstate commerce") is held to be outside the exclusion of Section I as not being a "contract of employment" as contemplated by the exclusion, it seems quite clear that since the employees are engaged either in 
foreign or in interstate commerce or within the jurisdiction of admiralty, the collective bargaining agreement may qualify either as a "maritime transaction," or if not, as a "contract evidencing a transaction involving commerce" so that the arbitration provision therein would qualify under Section 2. (3) Given either a "contract of employment" or a collective bargaining agreement between an employer and a union of his employees who are outside the categories designated in the exclusion ("seamen, railroad employees, or any other class of workers engaged in foreign or interstate commerce") it seems clear that it will not plausibly fit into the Act either as a "maritime transaction" or "commerce" and that an arbitration provision therein will not qualify under Section 2.

\section{V}

\section{Concerning Arbitration Provisions Designating Where Arbitrations Sfard Be Held}

Two general questions have been raised in the federal courts with respect to arbitration provisions which designate a place in a foreign country or in a state where arbitrations thereunder shall be held. They are as follows: (I) If the arbitration provision otherwise qualifies under the Act (Section 2) will such designation disqualify the arbitration provision from any or all of the remedies of Sections 3, 4,5 , or 8 of the Act? (2) Will the courts, in their discretion, disregard the designation and order the arbitration to be held within the district of the court's jurisdiction? Diversities and contradictions in the law of the Act again appear.

Two district courts, in admiralty proceedings, ${ }^{85}$ denied, it seems, both a stay and order to arbitrate because the arbitration provisions called for arbitration in London.

These courts voiced the opinion that the United States Act does not authorize any court of the United States to apply the Act to an arbitration agreement which stipulates for foreign arbitrations. This opinion was based chiefly upon one sentence of Section 4 of the Act. That Section provides motion proceedings to obtain a general order against a recalcitrant party to proceed to arbitration in compliance with the agreement. The particular sentence of the Section which was deemed controlling in these cases, together with the sentence immediately preceding it, reads as follows:

The court shall hear the parties, and upon being satisfied that the making of the agreement for arbitration or the failure to comply therewith is not in issue, the court shall make an order directing the parties to proceed to arbitration in accordance with the terms of the agreement. The hearing and proceedings under such agreement shall be within the district in which the petition for an order directing such arbitration is filed (italics supplied).

The succeeding sentences of the Section provide for the trial of the making of the arbitration agreement and the alleged default thereunder when these matters r929).

${ }^{85}$ The Silverbrook, 18 F.2d I44 (E. D. La. I927); The Beechwood, 35 F.2d 4I (S. D. N. Y. 
(or either of them) are put in issue, and when the making of the agreement and the alleged default are found,

the court shall make an order summarily directing the parties to proceed with the arbitration in accordance with the terms thereof (italics supplied).

Section 8 of the Act, which also was involved in the foregoing cases, provides as follows:

§8. If the basis of jurisdiction be a cause of action otherwise justiciable in admirality, then, notwithstanding anything herein to the contrary, the party claiming to be aggrieved may begin his proceeding hereunder by libel and seizure of the vessel or other property of the other party according to the usual course of admiralty proceedings, and the court shall then have jurisdiction to direct the parties to proceed with the arbitration and shall retain jurisdiction to enter its decree upon the award (italics supplied).

In The Silverbrook, the first of the foregoing cases, the court observed generally that $^{86}$

the act seems to contemplate only such arbitration agreements as would be or could be carried out in the United States, within the jurisdiction of and under the control and orders of the United States Courts. ...

After reviewing the several sections of the statute the court elaborated upon this view as follows: ${ }^{87}$

The courts of the United States are of limited jurisdiction, being confined to the specific grants thereof by Congress. Although the basis of jurisdiction in this case is a cause of action otherwise justiciable in admiralty, and begun by a libel and seizure of a vessel according to the usual course of admiralty proceedings, and therefore of the class contemplated by section 8 of the United States Arbitration Act, this court is without jurisdiction to direct the parties to proceed to arbitration as required by the concluding clause of that section, because the place and manner of arbitration prescribed by the terms of the contract are beyond the jurisdiction of this court, since the hearings and proceedings thereunder cannot be held conformable to the terms of this statute, and particularly to section 4, which requires the arbitration to proceed within the district in which the petition for an order directing such arbitrations was filed. This court cannot direct and otherwise supervise and conclude an arbitration to be held in London, or assume to vacate, modify, or correct any award that might be made there, or, indeed anywhere, except within this district, nor has it power as a court of admiralty to arbitrarily reform, or modify the terms of the contract by ordering an arbitration elsewhere or otherwise than agreed upon by the parties.

It is difficult indeed to subscribe to these rulings. Although the arbitration provision otherwise qualifies under the Act (Section 2), the parties' stipulation of the place of arbitration outside the jurisdiction of the court-in these cases, in Londonapparently disqualifies the agreement from the whole Act. The Act comprehends arbitration provisions in "maritime transactions" and in contracts evidencing transactions involving "commerce." The place of arbitration is likely to assume consider-

${ }^{86}$ I 8 F.2d at I46 (italics supplied).

${ }^{87}$ Id. at 147 (italics supplied). 
able importance to the parties to such transactions and commerce, and it is not to be expected that the parties will always fix the place in the United States. Accordingly, it seems, there should be required more compelling reasons than were advanced in the foregoing cases, to render the whole Act inapplicable because the parties designate the place of arbitration in a foreign country.

By Section 3 of the Act a stay of trial shall be granted "until such arbitration has been had in accordance with the terms of the agreement" (italics supplied). None of the difficulties envisaged in the two foregoing cases seems to present any real obstacle against applying Section 3. A conforming order is readily drawn and entered, and will be equally effective upon the suit or action in the court whether the arbitration is to be held abroad or at home.

In a subsequent decision in the District Court for the Southern District of New York stay was granted in admiralty proceedings pursuant to Section 3 on an arbitration provision calling for arbitration in London. ${ }^{88}$ Said District Judge Patterson: ${ }^{89}$

The fact that the arbitration agreed upon in the charter party is to be held in a foreign country does not prejudice the owner's right to a stay of proceedings in this court.

Absent special "equitable considerations" of hardship, it seems clear that the remedies of Sections 4, 5, and 8 of the Act, like that of Section 3, should be accorded arbitration provisions, notwithstanding a foreign place of arbitration is stipulated. As we have pointed out above, a stay under Section 3, alone, leads to frustration and uncertainty of any arbitration being accomplished.

While, as a matter of technical interpretation of Section 4 with its own special language as contained in the foregoing sentence, the question is not beyond doubt, only modest "new orientation" will, we believe, support our conclusion.

${ }^{88}$ The Quarrington Court, 25 F. Supp. 665 (S. D. N. Y. 1938). Accord, International Refugee Organization v. Republic S. S. Corp., 93 F. Supp. 798 (D. Md. I950). Judge Patterson made no mention of The Beechwood, supra note 85. The order of stay in The Quarrington Court was reversed on appeal, but not because of the provision for arbitration in London. Indeed, it was indicated by the court of appeals that, absent other controlling considerations, the order of stay would have been proper. The Quarrington Court, I02 F.2d 916 (2d Cir. 1939).

The denial of stay in The Silverbrook, supra note 85 had been criticized earlier in Danielsen $v$. Entre Rios Rys. Co. 22 F.2d 326, 327 (D. Md., I927): "Such a holding seems erroneous under the broad language of section 3 , granting that section $4 \ldots$ of the act limits the jurisdiction of the court to order arbitration in connection with agreements performable within the United States."

Danielsen v. Entre Rios Rys. Co. supra, and The Fredensbro, I8 F.2d 983 (E. D. La. I927), involved libels in admiralty; the charter parties upon which the proceedings were based contained arbitration provisions calling for arbitrations in London. Exceptions to the jurisdiction of the court, including one based on the arbitration provision, were overruled. There were no rulings pertinent to the question at hand upon the applicability of Sections 3, 4, 5, or 8 of the Act. As a matter of pleading it may be conceded that an arbitration provision does not go to the jurisdiction of the court; and especially is this so in admiralty proceedings involving Section 8. See American Sugar Refining Co. v. Anaconda, 138 F.2d 765 (5th Cir. 1943), aff'd, 322 U. S. 42 (1944); Karno Smith Co. v. School District of City of Scranton, 44 F. Supp. 860 (M.D. Pa. 1942). Application should be made for an order for stay of trial under Section 3 or for the proper order under the other sections. Compare Evans v. Hudson Coal Co., 165 F.2d 970 (3d Cir. 1948).

Concerning The Volsino, 32 F.2d 357 (E. D. N. Y. r929), another case in this earlier group, see supra note $\mathrm{I}$.

${ }^{80} 25$ F. Supp. at 666. He cited Shanferoke Coal \& Supply Co. v. Westchester Service Corp., 293 U. S. 449 (1935), which is considered below. 
Section 4 embraces enforcement orders in two situations as follows. (I) When the making of the agreement for arbitration and the alleged default of the defending party are not put in issue; and (2) when these matters (or either of them) are put in issue and after the preliminary trial, are found in favor of the moving party. The troublesome sentence prescribing that the arbitral hearing and proceedings under the arbitration provision "shall be held within the district in which the petition for an order directing such arbitration is filed," appears only in succession to the provision for the first foregoing order (it is not included in the text of Section 5 , nor of Section 8). Provisions governing the granting of both orders repeat the very same text, namely, "the court shall make an order summarily directing the parties to proceed with the arbitration in accordance with the terms thereof" (italics supplied).

The position of the troublesome sentence is somewhat awkward if it were intended to apply to both orders under Section 4, i.e., an order to arbitrate whether without, or after, the prescribed trial of issues as to the making of the arbitration agreement or the default. Granting that the awkwardness could be ameliorated by repeating it to cover both orders or by translating it to the end of the Section so as to apply to both orders, it would not displace the twice repeated text of that Section that orders thereunder shall direct the parties to proceed to arbitration "in accordance with the terms of the agreement."

In short, the position of the troublesome sentence is not so commanding that it should be held to nullify both positive provisions of the same Section that the order to proceed shall issue "in accordance with the terms" of the clause. It seems more reasonable to take the position that while Section 4 with the foregoing troublesome sentence (that the arbitration hearing and proceedings "shall be held within the district in which the petition for an order directing such arbitration is filed") should be construed as applying to an arbitration which is held under either of the foregoing orders for arbitration, it should so apply only when there is occasion for such provision to be effective, namely, when the arbitration agreement does not specify another place (outside the district) where the arbitration shall be held. These conclusions would likewise facilitate the administration of Sections 5 and 8 of the Act. ${ }^{00}$

With respect to the last clause in Section 8, which provides that the court shall have jurisdiction "to direct the parties to proceed with the arbitration and shall retain jurisdiction to enter its decree upon the award," it is easier to regard it as enabling,

\footnotetext{
${ }^{\circ 0}$ In the Senate hearings upon the original bill it is indicated that the foregoing sentence of Section 4 was conceived and added to the bill so that "it is not permissible to drag a man across the country to arbitrate." 66 Cong. Rec. $276 \mathrm{r}$ (1925).

While this slogan might have some appeal in behalf of the "underdog," it is impossible to identify in advance who will be dragging whom to arbitration and it seems rough indecd to deny absolutely the power and privilege of competent parties to contract where their arbitrations shall take place. We believe that it is more plausible in proceedings under Sections 4,5 , and 8 to honor the agreement of the parties if they fix a place for their arbitrations unless and until substantial inconvenience and injustices are made to appear. If no place of arbitration is designated or if the place designated is to be disregarded for cause, it seems equally clear that the hearing is properly ordered within the district of the federal district court having jurisdiction and venue as prescribed in the U. S. C. $\$ \$ 391$ and $140_{4}(\mathrm{a})$.
} 
and inclusive of an arbitration had and award rendered in a foreign arbitration, than as being restrictive and applicable only to an arbitration which is conducted within the district in which the libel and the petition for the order to proceed are filed.91

We now turn to the decisions under the Act dealing with an arbitration provision calling for arbitration within or outside the district of the federal court but in a designated state of the United States. Will the view of the foregoing courts relating to arbitration provisions fixing arbitration in a foreign country be equally applicable? And suppose that the arbitration statute of the state is of the same general pattern as the United States Act, and further that the arbitration provision may qualify thereunder?

The Court of Appeals for the Ninth Circuit has considered this general problem in two cases which were brought in a federal district court for a district of California. In the first, California Prune \& Apricot Growers' Ass'n v. Catz American Co., ${ }^{92}$ the arbitration provision called for arbitration of disputes arising out of a contract to buy and sell prunes before the Dried Fruit Association of California. The petitioner (appellee) contracted to buy appellant's entire stock of 1926 California prunes. Controversy arose and the buyer, a New York corporation, petitioned for an order against the seller, a California corporation, to proceed with arbitration. The petitioner invoked the jurisdiction of the district court on the ground of diversity of citizenship of the parties. The district court granted the petition and ordered the parties to proceed to arbitrate according to the terms of the arbitration provision. The court of appeals reversed. The issue, as reported by the court of appeals, was whether the district court had jurisdiction to order arbitration in accord with the California arbitration statute. Why this was made the issue is not entirely clear, ex-

${ }^{21}$ The suggestion in The Silverbrook, supra note 85 , that the court could not take jurisdiction to accord the remedies of Sections 3 or 4 of the Act with respect to the forcign arbitration "since the hearing and proceedings thereunder cannot be held conformable to the terms of the statute," ( 18 F.2d at 147 ) does not appear to have sufficient basis to support the court's ruling. Indeed, it is not clear what the court meant, if more than that the arbitration hearing would not proceed conformably to the statute within the district in which the petition is filed if it were had in London. Otherwise the foreign hearing and award could follow the statute. Whether the hearing (or the award) shall have conformed to the statute in the given case would be open to challenge and determination were the statute ever invoked to enforce or vacate an award rendered therein.

That the court could not, as was said in The Silverbrook ( 187 F.2d at 147 ), "direct and otherwise supervise and conclude an arbitration to be held in London" may be conceded, but neither could it, nor would it, do so if the arbitration were to be held within the district. The court is not expected, nor authorized, to "supervise" or "conclude" the arbitration.

Nor does it seem material, though voiced in The Silverbrook, that the court could not "assume to vacate, modify or correct any award that might be made there [in London]." I 8 F.2d at I47. These considerations are more remote and speculative than the court scemed to indicate. Whether there will be cause under the Act to vacate or to modify or correct will depend upon what happens in the proceedings and in rendering the award. It seems clear that the court would retain jurisdiction after an order entered pursuant to either Section $3,4,5$, or 8 , sufficient at least to receive a motion to confirm an award under Section 9, or to vacate an award under Section Io, or to modify or correct under Section Ir. Section 8 seems particularly clear on this point. See, in this connection, The Gerald A. Fagan, 49 F.2d 215 (2d Cir. 193x).

${ }_{03}^{3} 60$ F.2d 788 (9th Cir. 1932). Compare Pacific Indemnity Co. v. Ins. Co. No. America, 25 F.2d 930 ( 9 th Cir. 1928) in which stay of trial was granted relying upon the California arbitration statute. No reference was made, however, to the matter now under consideration. 
cept that the parties argued the case on that basis and the appellee sought to sustain the order by the district court on the basis that the federal court in this diversity case should accord it the same relief as it would be entitled to under the state statute. Perhaps the petitioner (appellee) feared that the contract containing the arbitration provision did not, on the facts, constitute a contract evidencing a transaction involving "commerce" as required in Section 2 of the United States Act and that, therefore, the arbitration provision did not qualify under that Act. Otherwise, it seems, the petitioner (appellee) should have invoked the United States Act and sought the very order which, apparently, the district court granted, namely, that the arbitration proceed in accordance with the terms of the arbitration provision. Under such order, it seems clear that the arbitration proceedings and the rendering of the award should follow the United States Act (not the California Act if and as it differs from the United States Act with respect to these matters) to qualify the award for confirmation and enforcement under Section 9 of the Act.

The court of appeals in deciding the issue as presented commented as follows: $:^{03}$

The act [of California] itself discloses that it was the intention of the Legislature to provide a procedure peculiarly adaptable to the state courts of California; and in view of many of the provisions of the act, it would be difficult if not impossible to harmonize it with the federal law and procedure.

The court also added:

The law that controls in the matter of the remedy is the law of the forum, and no other. The federal courts are without jurisdiction or power to enforce a purely remedial or procedural state law.

The subsequent case, Hudson Lumber Co. v. United States Plywood Corp. ${ }^{04}$ involved an action for declaratory ruling as to the interpretation of a contract between the parties. It was brought originally in a California state court and was removed by the defendant to a federal district court for a district of California. Application for stay was made by defendant relying upon Section 3 of the United States Act. What was the basis upon which jurisdiction of the federal court was invoked, whether on diversity of citizenship, or otherwise, does not appear, nor does it appear how the arbitration provision qualified under the Act (Section 2). These matters were not put in issue nor considered by the court. The arbitration provision in the contract provided that disputes arising thereunder "shall be submitted to arbitration in the State of California pursuant to the Rules of the American Arbitration Association...." Held, that stay of trial was properly granted. No question was raised, nor was any considered by the court, concerning the significance or effect of the foregoing provision that arbitration should be in the state of California. ${ }^{00}$

${ }^{83} 60$ F.2d at 790.

24 I8I F.2d 929 (9th Cir. 1950).

${ }^{\circ 5}$ Id. at 930 .

${ }^{\circ 8}$ The Gerald A. Fagan, 49 F.2d 215 (2d Cir. 193I) involved a libel in admiralty in rem and in personam and alleged breach by ship owner of a contract to supply canal tonnage to charterer. It was 
In the second circuit in Shanferoke Coal \& Supply Corp. v. Westchester Service Corp. ${ }^{97}$ plaintiff seller, a Delaware corporation, sued the buyer, a New York corporation, in the federal District Court for the Southern District of New York to recover damages for alleged breach of the contract. The contract contained an arbitration provision which stipulated that if an arbitration shall fail for any reason "either party may apply to the Supreme Court of the State of New York for an order compelling the specific performance of the arbitration agreement in accordance with the arbitration laws of the State of New York."

The defendant invoked the enforcement of this provision by an application for stay under Section 3 of the United States Act. The district court denied the motion on the ground that the terms of the arbitration provision confined the parties to an arbitration "in the Supreme Court of New York" and that a stay would involve such superintendence as the district court was unfitted to undertake. The order denying stay was reversed by the court of appeals.

Judge Learned Hand voiced doubt as to the district judge's view that the arbitration provision necessarily limited the parties to an arbitration "in the state court" as follows : ${ }^{98}$

We do not find it necessary to decide whether the arbitration clause at bar was limited to a proceeding in the state court. While it is certainly possible to read the language only as an addition, redundant because already provided by law, and as not intended to prevent arbitration elsewhere, we are content to treat it as exclusive, as the judge did.

Notwithstanding, therefore, that the arbitration provision may have been intended to restrict its enforcement to the New York courts the district court was authorized and required to order the stay.

In support of the ruling of the court of appeals, Judge Hand noted that Section 3 "specifically provides for a stay, and we have only to decide whether it covers the situation; that is whether the arbitration must be in a federal court." (Just what the district judge and Judge Hand, respectively, may have meant by the arbitration being

instituted in the District Court for the Southern District of New York. The contract contained an arbitration provision calling for arbitrations thereunder to be "before the Committee on Grain of the New York Produce Exchange." Without giving attention to the point now under consideration the district court ordered arbitration and thereafter entered final decree in admiralty confirming the award rendered in the arbitration. This decree was entered in reliance upon Section 8 of the Act and was affirmed by the court of appeals.

In Petition of Pahlberg, $x_{3}$ I F.2d 968 (2d Cir. 1942) charterers instituted libel in admiralty in the District Court for the Southern District of New York against ship owners to recover damages for alleged breach of agreement to charter. The charter party contained a provision for arbitration "to be referred to three persons at New York." Motion by the owners under Section 4 to order the charterers to proceed to arbitration and to appoint their arbitrator as agreed in the provision was granted by the district court, 43 F. Supp. 76I (S. D. N. Y. I942). The order was affirmed on appeal by the court of appeals. The point now under consideration was not discussed. Like holding was made in Stathatos v. Arnold Bernstein Corp., 87 F. Supp. roo7 (S. D. N. Y. 1950) (arbitration provision that controversies "be referred to three persons in the City of New York"). See also Arnold Bernstein Shipping Co. v. Tidewater Commercial Co., 84 F. Supp. 948 (D. Md. 1949); Goldbill Trading \& Ship Co. v. Caribbean Ship Co., 56 F. Supp. 31 (S. D. N. Y. 1944).

${ }^{07} 70$ F.2d 297 (2d Cir. 1934).

${ }^{\circ 8}$ Id. at 298. 
"in the Supreme Court of New York" or "in a federal court," is not clear.) Judge Hand concluded:" "We can see no reason for a limited construction, and conclude that section 3 authorizes a stay even though the arbitration must take place beyond the jurisdiction of the court."

Before coming to this conclusion, and, apparently in deciding whether the Section "covers the situation," he observed: ${ }^{100}$

The decisions in the District courts are divided. The Silverbrook (D. C.) I8 F.2d r44, The Fredensbro (D. C.) r8 F.2d 983, and the Beechwood (D. C.) 35 F.2d 4I, take the view of the judge below; Danielsen v. Entre Rios Rys. Co. (D. C.) 22 F.2d 326, and The Volsinio (D. C.) 32 F.2d 357 (semble), are contra. ${ }^{101}$ So too is In re Interocean Food Products, Inc. v. York Mercantile Co., 206 App. Div. 426, 201 N. Y. S. 536.102

Although only the order denying a stay under Section 3 was in issue on the appeal, Judge Hand did add that on the basis of the foregoing view of the district court judge (conceded for purposes of the decision on appeal) that the arbitration provision restricted the parties to an arbitration in the supreme court of New York the district court could not "enforce the clause specifically" citing California Prine \& Apricot Growers' Ass'n.

In ruling upon the precise matter in issue, namely, that stay of trial was proper pursuant to Section 3, Judge Hand denied the validity of the district judge's view that to order the stay would require superintendence beyond the competence of the district court. He conceded that "it may from time to time be necessary for the court where the action is pending to consider how far he [the defendant obtaining the stay] has continued to perform. Even so, the superintendence involved is not beyond the compass of a court of equity. . .."

The Shanferoke case went to the Supreme Court on certiorari for review of the foregoing decision of the court of appeals. The decision was affirmed. The Supreme Court observed that the matter at issue before the courts below and before it concerned only the validity of a stay under Section 3 and did not concern any questions of "specific enforcement" of the arbitration provision otherwise. Said the Court: $:^{103}$.

The contract does not in terms prohibit proceedings in the federal court. Whether it should be construed so as to exclude the bringing of a suit in the federal court to ${ }^{\circ 0}$ Ibid. ${ }^{200}$ Ibid.

${ }^{10 x}$ That we have diffculty with Judge Hand's alignment of the decisions in the cases cited, see, stipra note 88.

${ }_{102}$ Supreme court decisions in New York are in accord that an out-of-state arbitration will not be ordered, but that a stay of trial will be. The court of appeals has not ruled upon these questions. The supreme court of Pennsylvania has ordered the out-of-state arbitration (Nippon Ki-Ito Kaisha, Lt'd v. Ewing-Thomas Corp., 313 Pa. 442, I70 Atl. 286 (I934), and so has the Essex County Court (New Jersey). In re California Lima Bean Growers Ass'n, 9 N. J. Misc. 362, 154 Atl. 532 (I931). Sec also Rosenthal v. Berman, I4 N. J. Super. 348, $82 \mathrm{~A} 2 \mathrm{~d}$. 455 (1951), Sturges and Ives, Some Confusing Matters Relating to Arbitration in Pennsylvania, 99 U. of PA. L. REv. 727, 757 (1951).

${ }^{103}$ Shanferoke Coal \& Supply Corp. v. Westchester Service Corp., 293 U. S. 449, 452 (1935). That we have difficulty in identifying orders of stay under Section 3 as substantially different from "specific performance" orders under Sections 4,5 , or 8 , see, supra, note 43 . 
compel specific performance of the agreement to arbitrate, we have no occasion to decide. For the District Court was not asked, in the proceedings now under review, to compel specific performance. The motion was to stay the action until arbitration shall have been had; and the direction of the Court of Appeals was limited to granting a stay.

Notwithstanding this particularization of the issue to be decided in this case, namely, that it related only to a stay of trial and not to "specific performance" of the arbitration agreement, the Supreme Court did go on to observe as follows: "We think the Court of Appeals was clearly right in concluding that there is no reason to imply that the power to grant a stay is conditioned upon the existence of power to compel arbitration in accordance with $\S_{4}$ of the Act." Why this was deemed pertinent in light of the foregoing statement of the limitation of the matter on review is not clear. Is it to be inferred that the Supreme Court intended to indicate that orders under Sections 4,5 , or 8 would have been beyond the jurisdiction of the district court in such a case as did Judge Hand? The statement as made seems not to have been at all necessary to the disposition of the cause in issue before the Court.

In a footnote to the last quoted statement of the Supreme Court the following was appended:104

In the lower federal courts there has been some difference of opinion as to whether a stay should be granted when the court is not in a position to compel arbitration.

The Court cited the following cases to this statement: ${ }^{105}$

Compare Danielsen v. Entre Rios Ry. Co., 22 F.2d 326, 328, with The Silverbrook, I8 F.2d I44. See, too, The Beechwood, 35 F.2d 4r; The Volsinio, 32 F.2d 357, 358; Ex parte De Simon, 36 F.2d 773; The Fredensbro, I8 F.2d 983. ${ }^{106}$ Interpretations of the English arbitration statutes are in accord with the view adopted here. [Citing British cases.]

We have difficulty in finding from this review of the decisions any substantial basis under the Act for denying remedies under Sections 4, 5, or 8 because the parties have stipulated that the arbitration shall be held in a foreign place or elsewhere outside the district of the Court. The Act, we submit, preponderates in text to require that such arbitration provisions (otherwise qualifying under the $\mathrm{Act}$ ) shall, to the extent of the powers of the courts of the United States, be ordered enforced "in accordance with the terms" of the provisions. Difficulties of supervision or control over the arbitration are not real because supervision or control is not authorized or required under the Act even when the arbitration is had within the district over which the court has jurisdiction.

But suppose that the out-of-state arbitration is stipulated and that jurisdiction under the Act to order performance under Sections 4, 5, or 8 "in accordance with the terms" of the provision is settled. Will the foreign or out-of-state arbitration be ordered without question as to the reasonableness of the order? It seems fair to

${ }^{104} \mathrm{Id}$. at 453 . ${ }^{105} \mathrm{Ibid}$.

100 That we have difficulty with this alignment of the cases (as we did with that of Judge Hand, supra note Ior) see, stipra note 88. 
conclude that the court, in hearing applications under those Sections should, in so far as they relate to the fixing of the place of arbitration, temper or deny the application when substantial and undue hardship to a party, which was not reasonably anticipated when the agreement was made, is made to appear by clear and substantial evidence. Indeed, we submit that the same consideration with respect to such arbitration provisions on that question should be deemed pertinent upon an application for order of stay of trial under Section $3 \cdot{ }^{107}$

Such a ruling may have been involved in a case before the Court of Appeals of the Ninth Circuit. In Continental Grain Co. v. Dant \& Russell, Inc. ${ }^{108}$ the court of appeals affirmed an order of the District Court for the District of Oregon, which ordered arbitration within the district notwithstanding the arbitration provision called for arbitrations by three arbitrators in New York. The application was initiated in admiralty; the arbitration provision was in a charter party; the petitioner invoked both Sections 4 and 5 of the Act to gain the court's general order to arbitrate and order that the defending party appoint its arbitrator pursuant to the arbitration provision. The defending party opposed the petition on grounds to the effect that its place of business was in Oregon, its witnesses were there, and petitioner had a place of business in Oregon; he alleged his willingness to arbitrate in Oregon but not in New York. The district court ordered that the arbitration proceed in Oregon. Petitioner appealed from the order. The court of appeals relied upon the sentence in Section 4, heretofore considered troublesome, as follows: ${ }^{100}$

In the statute [Section 4] the clause under consideration with reference to the place of arbitration is in the form of a proviso reading as follows: ". . . the court shall make an order directing the parties to proceed to arbitration in accordance with the terms of the agreement: Provided, That the hearing and proceedings under such agreement shall be within the district in which the petition for an order directing such arbitration is filed."

The court concluded as follows: ${ }^{110}$

The appellant challenges the right of the court to order the arbitration within the district of Oregon because such an order does not conform to the agreement of the parties for an arbitration in New York. . . The Appellant, having invoked the jurisdiction of the United States District Court for Oregon is hardly in a position to complain that it has exercised that jurisdiction in accordance with the statute giving it jurisdiction.

In so far as the court relied only upon the troublesome sentence of Section 4 to derive the foregoing decision, our foregoing considerations lead us to question its validity. In so far as it was prompted by considerations of unforeseen hardship to

${ }^{10 z}$ See sispra note 43.

When a place of arbitration is stipulated in an agreement of submission of a controversy already existing between the parties (as distinguished from a provision to arbitrate disputcs arising in the future) it seems clear that substantial and undue hardship for the purpose now under consideration would be very difficult to establish.

${ }_{108}$ Ir 8 F.2d 967 ( 9 th Cir. 194I).

${ }^{100} \mathrm{Id}$. at $968-969$.

${ }^{110} \mathrm{Id}$. at 969 . This ruling appears to run counter to the suggestion of the court in The Silverbrook, stipra note 85 , and quoted at p. 620 stupra. 
the defending party and correlative want of prejudice to the petitioner, we believe that the result should be sustained. There should, of course, be adequate balancing of the hardship and prejudice to the respective parties in determining whether or not their stipulation as to the place of arbitration shall be disregarded. The items urged by the defending party are suggestive, but the record of the case on this matter is scarcely adequate to judge their merit in the particular case.

\section{Conclusions}

We believe that the Act would be made to serve its purpose best if the courts of the different circuits would get together in uniform regard for the controlling effect of Section 2 of the Act. While this would limit the applicability of the Act, let its extension be determined and accomplished by legislative amendment. Diversities and contradictions in the different circuits concerning what arbitration agreements may qualify under the Act for the various remedies of Sections 3, 4, 5 , and 8 render the Act least useful to parties who may consider the use of arbitration agreements and arbitrations under it. We also believe that District Judges McGranery and Weinfeld have been more realistic than their brethren by identifying collective bargaining agreements out of "contracts of employment" as the latter term is used in the exclusion in Section I.

Arbitration statutes like the United States Act with provisions making qualifying arbitration agreements irrevocable and enforceable are, as pointed out above, effective to overcome common law revocability and non-enforceability. If parties wish to stipulate that the statute shall not apply to their arbitration agreements and arbitrations they may do so and engage common law. On the other hand, they are unable effectively to stipulate irrevocability and enforceability at common law. The statute provides the alternative-a freedom of choice as the parties shall agree. To facilitate this choice by the parties we believe that the United States Act should be extended by legislative amendment to cover arbitration agreements and controversies beyond those presently covered in Section 2 as we have suggested above. In furtherance of this end we submit that Section $x$ should be repealed and that Section 2 should be amended to remove its reference to and dependence upon the definitions now in Section I. It also would be well, we submit, to amend Section 4 by eliminating the troublesome sentence discussed above. Clarity also could be added to several other sections by further refinement in draftsmanship. 


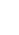

